\title{
The Political Determinants of
}

\section{Government Bond Holdings}

\author{
Stefan Eichler ${ }^{1}$ \\ Timo Plaga ${ }^{2}$
}

March 2016

\begin{abstract}
This paper analyzes the link between political factors and sovereign bond holdings of US investors in 60 countries over the 2003-2013 period. We find that, in general, US investors hold more bonds in countries with few political constraints on the government. Moreover, US investors respond to increased uncertainty around major elections by reducing government bond holdings. These effects are particularly significant in democratic regimes and countries with sound institutions, which enable effective implementation of fiscal consolidation measures or economic reforms. In countries characterized by high current default risk or a sovereign default history, US investors show a tendency towards favoring higher political constraints as this makes sovereign default more difficult for the government. Political instability, characterized by the fluctuation in political veto players, reduces US investment in government bonds. This effect is more pronounced in countries with low sovereign solvency.
\end{abstract}

JEL classification: G11; G15; G18; H63; H11

Keywords: Government bond portfolio; Political factors; Treasury International Capital data; PPML

\footnotetext{
${ }^{1}$ Leibniz University Hannover, Department of Business and Economics, Institute of Money and International Finance and Halle Institute for Economic Research, Halle, Germany, eichler@gif.uni-hannover.de

${ }^{2}$ Leibniz University Hannover, Department of Business and Economics, Institute of Money and International Finance, plaga@gif.uni-hannover.de
} 


\section{Introduction}

Decisions to safeguard fiscal sustainability or to default on sovereign debt are often made based upon political considerations. Eventually, the decision to default on sovereign debt generally falls into a legal void and is left to the government in charge. Since sovereign default risk is a crucial determinant of government bond performance, investors take political factors into account when investing in government bonds. Seeing as foreign investors play a crucial role in many government bond markets (particularly in emerging market economies), unfavorable political environments can deteriorate the government's financing conditions by deterring foreign investors. This paper focuses on the political determinants of US investors' government bond holdings.

Several interesting strands of the literature have investigated the determinants of bond holdings in general (Burger and Warnock, 2003; Lane, 2005; Fidora et al., 2007; Ferreira and Miguel, 2011; Vanpee and De Moor, 2012; Burger et al., 2014), as well as the sovereign bond holdings of banks (Angeloni and Wolff, 2012; Battistini et al., 2013; De Bruyckere et al., 2013; Buch et al., 2013; Gennaioli et al., 2014; Acharya and Steffen, 2015). The literature here focuses on macroeconomic fundamentals and financial market variables. Moreover, there are several interesting papers analyzing the impact of political variables on sovereign default risk. These papers find that elections (Block and Vaaler, 2004), political stability (Huang et al., 2015), or political constraints on the government (Boubakri et al., 2011; Breen and McMenamin, 2013; Eichler, 2014) significantly affect sovereign default risk as assessed by investors.

The present paper contributes to the existing literature in several ways. To the best of our knowledge, we are the first to focus on the impact of political factors on US investors' sovereign bond portfolio holdings. Our analysis thus reveals how political factors attract or deter US investors from investing in host countries' sovereign bonds, with important implications for the international refinancing conditions of the governments studied. We use data taken from the Treasury International Capital (TIC) system, which provides high quality information on 
government bond holdings of all US-based institutional and individual investors. Given the portfolio structure of the data, we estimate gravity models using the Poisson Pseudo Maximum Likelihood (PPML) procedure. In addition to the unconditional effect of political factors on US investors' government bond holdings abroad, we use interaction models in order to detect whether the effect of political environments on bond holdings depends on the quality of institutions, sovereign solvency, or the characteristics of the political regime.

Using data on US investors' foreign sovereign bond holdings in 60 countries over the 2003-2013 period, we find that, in general, US investors increase their government bond holdings when political constraints are low. This suggests that US investors prefer political regimes where the government has sufficient power (such as the control of all houses and a low level of checks in the political system) to implement or change fiscal measures whenever needed. US investors respond to the political cycle: We find that around the time of major elections, government bond holdings decrease, indicating that US investors experience increased uncertainty with regard to future economic policy. In addition, political instability, characterized by a fluctuation in the number of political veto players, is associated with lower bond holdings. For ideology of the governing party, we do not find significant unconditional effects.

Using interaction models, we analyze the impact of political factors on US investors' government bond holdings by distinguishing between host countries along several dimensions such as institutional development, sovereign solvency and the type of political system. We find that US investors differ in their assessment of political factors based on these structural characteristics: US investors appreciate a low level of political constraints (implying a high feasibility of policy change), given that these countries are democratic and their respective institutions are sufficiently developed. US investors appear to believe that unconstrained governments can only effectively safeguard fiscal stability when they act within a strong institutional environment that allows efficient implementation of fiscal consolidation or 
economic reform packages. Likewise, elections do not significantly affect government bond holdings if institutions are relatively poor, indicating that US investors do not believe that elections will lead to a real shift in economic policy if relevant institutional prerequisites are not present.

Moreover, a low level of political constraints increases US government bond holdings for countries which have a good sovereign credit rating and have not defaulted in the past. For countries with poor credit ratings or a sovereign default history, US investors appear to appreciate higher levels of political constraints, which reduce the political risk of the government defaulting on sovereign debt. What is more, the negative effect of a turnover in veto players on US bond holdings is much more pronounced in countries with high levels of sovereign debt, high current sovereign default risk, or a history of sovereign default. A comparison of political regimes reveals that political constraints, political business cycles and political instability have negative effects on US bond holdings in parliamentary regimes only. In presidential regimes, where the government is not dependent on the support of other parties within the government (as is the case in coalition governments), these political factors have no significant effect for the most part.

The rest of the paper is organized as follows. Section 2 reviews the literature. Section 3 discusses the data and variables used in the study and section 4 presents the empirical analysis. Section 5 concludes.

\section{Literature}

Three strands of the literature are relevant to our study. The first strand analyzes the determinants of foreign bond portfolios in general, while not focusing on sovereign bonds. These studies typically seek to explain the home bias in international bond holdings, i.e., deviations of actual portfolio positions from the world market portfolio as predicted by the international asset pricing model (ICAPM). The second strand investigates banks' government 
bond portfolios, particularly during the eurozone crisis, though none of these papers focuses on the role of political factors. The third strand of papers investigates the role political factors play in sovereign default risk. To the best of our knowledge, no study exists to date which focuses on the impact of political factors on the structure of government bond portfolio holdings.

\section{Home bias in international bond holdings}

Burger and Warnock (2003) use data from the US Treasury International Capital (TIC) system to explain home bias in US investors' foreign bond holdings in more than 40 countries. In the econometric analysis, they explain end-2001 US portfolio weights and find that capital account openness is positively associated with US bond holdings, while a higher return correlation with US bonds reduces holdings. However, this result disappears when bond holdings are disaggregated into local currency and US Dollar-denominated bonds. Comparing US bond holdings in 2001 to 1997, they find that US investors moved into more developed bond markets and away from countries with smaller markets and poor credit ratings.

Burger et al. (2014) also use TIC data and investigate the effects of bond yields, macroeconomic indicators, institutional variables and openness on local currency and US Dollar-denominated bonds separately. They also test the role of global "push" factors such as the US Treasury rate and the volatility index VIX. Running panel fixed effects regression for 28 destination countries over the 2006-2011 period, they find evidence that US investors reallocated towards local currency bond markets in emerging markets with higher bond yields, faster economic growth, more positive current account balances and more stable inflation.

Lane (2005) examines the bilateral composition of international bond portfolios for member countries of the European Monetary Union (EMU) using data from the IMF Coordinated Portfolio Investment Survey. In a cross-sectional regression with 11 EMU member countries and 11 other high-income countries from outside the EMU, he finds that the level of cross-border bond investment between two members of the euro area is about twice as high as 
between two countries which are not members of the EU, even after controlling for a set of other relevant variables. Comparing bond holdings between 1997 and 2001, he finds that bond holdings increased significantly quicker between members of the euro area.

Ferreira and Miguel (2011) study international bond holdings in the 1997-2009 period for 42 countries using Coordinated Portfolio Investment (CPIS) data from the IMF. Their results show that domestic bond bias is lower in economically developed countries, as well as in countries with few capital account restrictions and developed bond markets. Familiarity variables such as common language, geographical proximity and bilateral trade also decrease home bias. Bond return correlation is negatively associated with home bias, indicating that investors do not exploit diversification opportunities.

Vanpée and De Moor (2012) analyze the main differences in equity and home and foreign bond bias. They find that, for the most part, the level and growth of government debt increases the home and foreign bond bias. Furthermore, indicators of the quality of government institutions and corporate governance matter more for equity portfolios than for bond portfolios, while the level of financial development is more important for attracting bond investments.

Fidora et al. (2007) focus on the role of real exchange rate volatility in explaining home bias in global bond and equity markets. In their theoretical model, real exchange rate volatility increases home bias relatively more for assets with a relatively low level of local currency return volatility. As the authors argue, this implies that a change in real exchange rate volatility should have a larger impact for bond holdings than for equity holdings. Using data from the CPIS for 40 investor countries and up to 120 destination countries, they find that real exchange rate volatility is positively associated with home bias in bond and equity holdings. Indeed, this effect is significantly more pronounced for bonds. They also test the impact of institutional factors. Institutions associated with lower levels of investment risk, political risk, external conflict, corruption and inflation, as well as institutions associated with higher levels of judicial 
efficiency and quality of information disclosure, mitigate home bias in international bond holdings.

\section{Sovereign bond holdings of banks}

A more recent branch of the literature investigates the government bond holdings of banks, particularly in the context of the financial crisis in the eurozone. Buch et al. (2013) employ detailed bank-level panel data for German banks from the Deutsche Bundesbank's Security Holdings Statistics. They find that German banks have only adjusted their sovereign bond portfolios according to macroeconomic fundamentals since the collapse of Lehman Brothers. They do not find evidence that sovereign bond holdings increased bank risk as measured by the z-score.

Gennaioli et al. (2014) use data from Bankscope, which contains balance sheet information for a large number of banks all over the world during the 1998-2012 period. Identifying episodes of sovereign default, the authors investigate how public bond holdings have changed and how this transmits to the lending behavior of banks. They find that relative to small banks, large banks have increased their bond holdings during default years, on average. What is more, given a sovereign default takes place, banks' bond holdings at the time before the default are negatively associated with subsequent lending activity.

Other studies analyze banks' sovereign bond holdings with information published by the European Banking Authority (EBA) in the context of stress testing European banks. Acharya and Steffen (2015) demonstrate that eurozone banks increased their exposure to peripheral government bonds, even as yield spreads on these countries' debt widened between March and December 2011. They find a home bias for peripheral banks, which they partly explain through the result that peripheral banks which were bailed out held a significantly higher amount of domestic sovereign bonds. The authors view this as an indication of moral suasion, where the government induces domestic, intervened banks to hold more domestic sovereign debt. In 
addition, they find evidence that risk shifting and regulatory arbitrage played a role in driving investments into peripheral sovereign bonds.

Battistini et al. (2013) investigate the issue of fragmentation of eurozone financial markets commencing in late 2009 and the role of yield components. Consistent with the moral suasion and risk-shifting hypothesis, they find that only peripheral banks increase their exposure to domestic sovereign debt when the respective country risk factor rises. On the other hand, when the systemic risk factor rises, banks in all eurozone countries increase their home bias.

De Bruyckere et al. (2013) analyze sovereign bond holdings of banks in the context of risk spillovers between banks and sovereigns. They find that higher exposure to sovereign debt increases contagion between sovereign and bank risk.

Angeloni and Wolff (2012) relate the holdings of government debt by European banks to stock market performance during the European debt crisis. They find that, on average, banks holding considerable amounts of Greek debt suffered significant losses in terms of market value in the period July to October 2011. Thereafter, banks holding Italian, Irish and Portuguese debt were increasingly affected, while there was no measurable impact for Spanish government bond holdings.

\section{Political factors and sovereign risk}

Existing studies have mainly analyzed aggregated bond holdings but have placed little focus on explaining private and government bond holdings individually. What is more, the research on international bond holdings has so far paid little attention to the role of political factors. An important branch of research has instead emphasized the role of political factors in the context of investigating the determinants of sovereign default risk.

Block and Vaaler (2004) study the impact of the political business cycle on sovereign yield spreads and ratings. The political business cycle theory suggests that governments will 
implement expansionary fiscal policies prior to elections. The authors find that credit rating agencies downgrade the ratings of developing countries more often in election years, and that bond spreads are significantly higher in the 60 days leading up to the elections.

Manasse and Roubini (2009) derive typical characteristics of a sovereign debt crisis, finding that default risk rises prior to presidential elections, particularly if there are large amounts of short term debt and relatively rigid exchange rate regimes. On the other hand, given a sufficient level of fundamental economic factors such as a low level of debt, countries are relatively safe.

For a sample of developing countries, Saiegh (2009) finds that countries governed by a coalition of parties are less likely to reschedule their debts than countries ruled by single-party governments. In economic terms, the author finds that the mitigating effect of multi-party governments is of similar importance compared to fundamental factors such as the level of debt.

Boubakri et al. (2011) assess the impact of different political systems, political orientation, political stability and political cohesion on government bond yield spreads. Employing a fixed effects estimation using panel data for 35 developing countries over the 1993-2009 period, they find that presidential systems are positively associated with yield spreads. On the contrary, political competitiveness, a government having control of all houses, government majority and government tenure appear to have a mitigating impact on spreads.

Huang et al. (2015) assess the impact of international political risk on government bond yields in 34 countries from 1988-2007. As the results indicate, both the quantity of global political crises in a given year and the severity of the crises are indeed positively associated with government bond yields. The authors further demonstrate that domestic political stability and legal investor protection mitigate the adverse effect of global political risk on debt pricing.

Breen and McMenamin (2013) analyze long-term interest rates on government bonds in a panel of 23 developed countries between 1970 and 2009. They find that greater polarization 
leads to lower interest rates if concentration of political power is low, whereas polarization is positively associated with interest rates when concentration is high.

Kohlscheen (2010) studies actual sovereign default episodes and finds a lower default propensity in parliamentary democracies in a sample of 59 developing countries from 1976 to 2003. While he does not find a statistically significant effect of the number of political constraints on the likelihood of credit incidents, frequent changes in leadership increase the probability of a default.

Van Rijckeghem and Weder (2008) relate political and macroeconomic variables to the probability of default using a non-parametric technique. Taking annual data from 1974 to 2000 for 73 middle and low-income countries, they estimate thresholds given certain conditions above which default does not occur. The analysis makes a distinction with respect to the level of democracy and type of debt (domestic vs. foreign). Their baseline result is that political and institutional conditions seem to matter only in conjunction with economic conditions. In democratic regimes, parliamentary systems and a high number of veto players reduce the likelihood of default on foreign debt, provided that economic conditions are favorable.

Eichler (2014) tests the impact of a wide range of political variables on sovereign yield spreads by running fixed effects regressions for 27 emerging markets over the 1996- 2009 period. The results suggest that, on average, parliamentary systems and regimes with assembly elected presidents face significantly higher sovereign yield spreads than countries with presidential regimes. Countries with right-wing or left-wing governments are confronted with higher yield spreads compared to centrist governments. Additionally, the analysis of conditional effects with respect to different political systems suggests that spreads are generally more sensitive to political determinants in autocratic regimes than in democratic countries. In particular, variables indicating the feasibility of policy change and political stability appear to play a pronounced role under autocratic regimes. 
While the empirical literature on sovereign risk has established that political factors matter in the assessment of sovereign default risk, the research on actual bond holdings has largely ignored the role of political factors. As far as we are aware, there is no study to date which provides an empirical assessment of how various aspects of political institutions influence the portfolio holdings of government bonds. This study aims to close this gap.

\section{Data, Variables and Hypotheses}

We use unbalanced annual panel data for 60 countries (see Appendix Table 1) over the 2003-2013 period. Appendix Table 2 describes the definitions and data sources of the included variables. Appendix Table 3 provides summary statistics.

\subsection{Government Bond Holdings of US Investors}

Data on government bond holdings of US investors (our dependent variable) is taken from the US Treasury International Capital (TIC) System. ${ }^{3}$ The TIC system provides survey-based information on US residents' holdings of foreign securities by country measured at the end of each year. The survey collects data at the security level from US custodian banks, brokers other investors such as pension funds and foundations. The holdings data is measured in US dollars at market values. One advantage of the holdings data is that it is less subject to measurement bias than flow data, which typically reveals biased values with regard to the geographical origin of transactions. This is due to an important part of trading activity occurring in financial centers, resulting in a "transaction bias" (Bertaut and Judson 2014). Moreover, US position data is less subject to custodial bias, which arises if investors hold securities with a custodian in a different country. Such securities would then be mistakenly recorded against the home country of the custodian, leading to an incorrect geographical distribution of security holdings. Annual survey

\footnotetext{
${ }^{3}$ Data on bilateral bond holdings is also available for the IMF's Coordinated Portfolio Investment Survey (CPIS), which provides information on equity and bond holdings for a multitude of investor countries. However, the CPIS does not provide sectoral splits with respect to corporate and government bonds. We therefore opt for the TIC data as it provides detailed, high quality information on government bond holdings for US investors.
} 
data of US holdings of foreign securities is less vulnerable to custodian bias as it is collected at the security level, which allows for identification of the issuing country. Still, US security holdings may be underreported when US investors entrust their security holdings to foreign investment managers or custodians who do not report to the TIC system. Despite this, such underreporting is likely to be randomly distributed across countries and should not influence our results.

\subsection{Political Factors}

We include a broad range of political variables capturing the development and current shape of political institutions, as well as indicators related to the political cycle.

\section{Political constraints}

The first set of political factors measures the degree of political constraints faced by the executive party. One important factor shaping the level of political constraints is the role of veto players. In his work on political institutions, Tsebelis (2002) defines veto players as individual or collective actors who have to agree to proposed changes from the status quo. His central claim is that departures from the status quo are less likely the more veto players exist, and the greater the ideological distance is between them. Consequently, the number of veto players and the degree of ideological polarization is directly connected to policy stability. Tsebelis (2002) states that policy stability can generally be seen as the credible commitment of the political system not to interfere in economic, political or social interactions. Keefer and Stasavage (2003) find that multiple veto players indeed enhance the ability of governments to make credible commitments if they delegate monetary policy to an independent agency. Here, the more polarized the veto players are, the stronger the effect. Cuadra and Sapriza (2008) have a different prediction for the effect of ideological polarization in the legislature: In their model of political uncertainty, the incumbent party has the incentive to overspend as it knows that it might not be in office in the next term. This incentive increases with the ideological distance to 
the competing parties, as these prefer a different distribution of wealth. Furthermore, as is pointed out in Alesina and Drazen (1991), a government under divided rule will be less capable of carrying out economic reforms and delay stabilization because it will be susceptible to a war of attrition, characterized by political in-fighting and stalemates. As the authors point out, even if there is agreement on the need for a fiscal change, there is unlikely to be a consensus on how higher taxes or expenditure cuts should be allocated.

Summing up the conflict in the literature, the impact of political constraints and polarization on government bond holdings is ambiguous: On the one hand, US investors may appreciate strong, relatively unrestricted governments as they are generally able to depart from the status quo in order to improve fiscal sustainability and thus prevent sovereign default. On the other hand, the potential for higher policy instability and the weakened ability of unconstrained governments to make credible commitments may generate uncertainty surrounding future policy outcomes. In turn, this could increase the anticipated risk that an unconstrained government will default on its sovereign debt. How investors evaluate the political risks emanating from the level of political constraints is ultimately an empirical question.

We include the checks and balances variable from the Database of Political Institutions (DPI, Beck et al., 2001). This measure counts "the number of veto players in a political system, adjusting for whether these veto players are independent of each other, as determined by the level of electoral competitiveness in a system, their respective party affiliations, and the electoral rules" (Beck et al. 2001, p.170). Furthermore, we include variables from the DPI which reflect specific aspects of the level of political constraints faced by the governing party. First, we test the impact of concentration of power within a government, indicated by the Herfindahl index computed over the number of parties in the government. Second, we adopt an indicator of ideological polarization between the executive party and the four largest parties in the legislature. Ultimately, we include the margin of a government's majority and a dummy 
variable taking the value of 1 if the government controls all houses of the legislature, and 0 otherwise.

\section{Elections and stability}

We also test for a range of other variables related to the political cycle. We account for elections by including dummy variables taking the value of one if there is an election in the current or subsequent year, respectively, and 0 otherwise. Political business cycle theory suggests that the occurrence of elections induces governments to increase their likelihood of reelection by implementing economic policies that may harm post-election fiscal sustainability and economic growth. Indeed, there is empirical evidence that foreign investors take elections into account, at least in developing countries. For example, Block and Vaaler (2004) find that credit rating agencies downgrade the ratings of developing countries more often in election years, and that bond spreads are significantly higher in the 60 days prior to the election. As elections approach, investors may anticipate opportunistic behavior and adjust their bond holdings accordingly. Furthermore, uncertainty about the continuation of current policies may likewise be reflected in US bond holdings. With this in mind, we also include two dummy variables indicating years where the executive or incumbent government party is replaced after elections. What is more, a highly experienced executive or governing party may be considered an indicator of political stability. We thus include executive and governing party tenure in years. Furthermore, we account for the percentage of veto players (variable stabs in DPI) who drop from the government or legislature in any given year. This indicator captures the extent of turnover of key political players with veto power. A high turnover in veto players may signal political instability, which may, in turn, be reflected in US bond holdings.

\section{Ideology}

A political factor stressed in political business cycle (PBC) theory is the role of a government's ideological preferences. PBC theory suggests that right-wing policy preferences 
generally favor the interests of investors, whereas left-wing policies favor the interests of workers (Hibbs, 1977). In general, a right-wing government is expected to serve the interests of entrepreneurs by protecting property rights and implementing investor-friendly policies. Conversely, a left-wing government represents the interests of the laboring class and tends to promote a redistribution of wealth and restricting the rights of entrepreneurs. Vaaler et al. (2006) find that while countries governed by a right-wing party are more likely to be upgraded by rating agencies in non-election years, they are also significantly more likely to be downgraded when the incumbent government is expected to be replaced by a left-wing challenger. Using information from the DPI, we test for the impact of having a right-wing or left-wing party in power relative to a centrist executive party.

\section{Macro-Controls}

We control for a large set of variables reflecting macroeconomic fundamentals, the riskreturn profile of government bonds and the occurrence of financial crises. In order to control for the size of government bond markets, we include gross government debt from the IMF's World Economic Outlook (WEO) database. Data on the fiscal balance is obtained from the same source. Furthermore, we control for CPI inflation, GDP growth and the current account balance relative to GDP, obtained from the World Development Indicators (WDI). We also include a measure of capital account openness by Chinn and Ito (2007). To assess the role of bilateral trade integration, we adopt a measure of US total bilateral trade in goods (exports plus imports) relative to GDP. We include further control variables measuring the risk-return characteristics of sovereign bonds in order to capture the investment motive of US residents. In order to investigate whether US investors are driven by high returns or yields, we combine daily data from several government bond indices available in DATASTREAM, primarily the JP Morgan Emerging Markets Bond Index (EMBI) and Global Bond Index (GBI). To increase coverage, we complement these data with return and yield data from the Citigroup World Government Bond Index (WGBI) and the Merrill Lynch Government Bond Index. From these 
data, we then compute average daily returns per annum and the average yield. In order to account for potential diversification motives of investors, we compute the correlation coefficient between US and foreign country government bond returns. We also include average daily local equity returns, thus controlling for the relative attractiveness of equity investments. We also account for indicators of market volatility and crises. We include the standard deviation of daily bilateral exchange rate returns, equity returns and bond returns. Finally, we control for the event of a sovereign debt crisis by including a dummy variable taking the value of one if rating agencies declare a high credit risk, which is defined as a long-term, foreign currency rating worse than BB-. Through these measures, we end up with an unbalanced sample of 60 countries over the 2003-2013 period.

\section{Empirical Analysis}

We employ a gravity-style model where the amount of bilateral US government bond holdings in each individual country is modeled as the dependent variable. As Silva and Tenreyro (2006) demonstrate, the log-linearization of gravity models leads, in general, to inconsistent estimates if heteroskedasticity is present in the data. This is due to the fact that the expected value of the error in log-linearized models will generally depend on the covariates, leading to biased coefficient estimates. What is more, taking logs is infeasible for observations with the value zero. Omitting these observations from the sample, however, would mean excluding valuable information. In addition, this approach may result in selection bias if the excluded country-year observations differ systematically from the rest of the sample. Silva and Tenreyro (2006) suggest a Poisson pseudo-maximum-likelihood (PPML) estimation for gravity models, which deals with both problems. ${ }^{4}$

We estimate the following non-linear equation:

\footnotetext{
${ }^{4}$ What is crucial here is that in order to obtain consistent estimates, the data do not have to follow a Poisson distribution, and non-integer values for the dependent variable are unproblematic.
} 


$$
B H_{i, t}^{U S}=\exp \left(X_{i, t} \beta+\alpha_{t}+\mu_{i}\right)+\varepsilon_{i, t},
$$

where US government bond holdings in country $i$ in year $t$ (the dependent variable) are explained by a set of macroeconomic, financial and political variables captured in $X$. We also control for country and time fixed effects. Robust standard errors are clustered at the country level.

\subsection{Baseline Results}

Table 1 and 2 provide estimation results for the baseline models, testing one political variable in each specification. All models are estimated using the PPML estimator and include the same set of macroeconomic, financial and bond-specific variables, as well as country and year fixed effects ${ }^{5}$

For the variables measuring political constraints on the executive, our results support the hypothesis that investors, in general, favor powerful and relatively unconstrained governments. For example, if the government controls all houses of the parliament, US investments in government bonds are around 35\% higher than in years where the opposition controls the legislature. ${ }^{6}$ The negative coefficient of both the checks variable and the polarization indicator also suggest that investors prefer low levels of political constraints on the government. These effects are statistically significant, at the one percent level. Majority and Herfindahl government are not statistically significant, indicating that the government majority and concentration of power within a government do not influence US government bond holdings. In general, US investors appear to prefer investments in sovereign bond markets where a relatively unconstrained government has the political power to consolidate the budget or implement economic reforms in order to safeguard fiscal solvency. Thus, the results for the unconditional effects contradict the counterhypothesis that political constraints act as a

\footnotetext{
${ }^{5}$ The sample size varies with the data availability of the political variables examined. In particular, for ideology, sample size is reduced because information on party preferences is not always available in the DPI.

${ }^{6}$ Note that with PPML estimation, coefficients have to be interpreted as if the dependent variable were in logs.
} 
commitment device for sovereign debt repayment. However, the conditional results presented in Section 4.2 will provide a more detailed view on this issue since individual country characteristics (such as sovereign risk or the level of public debt) potentially determine the effect of political constraints on the government bond holdings of US investors.

For elections and stability, we find that government bond holders do adjust their portfolio with respect to the political cycle: In years where a major election takes place, government bond investors hold about $8 \%$ less bonds relative to non-election years. This is consistent with the view that US investors respond to increased uncertainty about post-election fiscal sustainability, which may be triggered through opportunistic behavior of the incumbent government. Moreover, political instability, measured by the drop in veto players, does exert a significant, negative effect on bond holdings.

For ideology, no significant differences in US government bond holdings are found among countries governed by right-wing, left-wing or centrist governments. A possible explanation for this finding is the varying levels of ideological differences between these political groups among the different countries considered. While in many emerging market economies the ideological differences between left and right-wing parties are substantial (particularly in terms of fiscal preferences), in industrialized countries left and right-wing parties are typically much more pragmatic.

Concerning the control variables, the results are largely in line with our expectations. The coefficient on the size of the government debt market is highly statistically significant in all specifications. The value of the coefficient of around $0.81^{7}$ in most specifications suggests that a $1 \%$ increase in government gross debt is associated with a $0.81 \%$ increase in government bond holdings of US investors, which is smaller than the unity coefficient predicted by the ICAPM. This implies that US investors adjust portfolio weights almost proportionally to

\footnotetext{
${ }^{7}$ When interpreting the size of the economic effects, we refer to the average value of a control variable's coefficient estimated for the different specifications.
} 
changes in the size of the government debt market. The coefficient on government bond returns of approximately 1.95 implies that a one standard deviation increase in daily government bond returns (equal to 0.062 percentage points, see Appendix Table 3) is associated with an increase in the government bond holdings of US investors of approximately $12.1 \%$. The coefficient on the correlation between domestic government bond and US treasury returns is statistically insignificant, suggesting no evidence for a potential diversification motive of US investors in selecting their government bond portfolio. We find some evidence that US investors respond to equity market performance: The coefficient on average equity return is negative and statistically significant in most specifications, indicating that high equity market performance induces US investors to reduce their government bond holdings. Market volatility, as indicated by the standard deviation of bond, exchange rate and equity returns, does not seem to deter US investments in government bonds.

For macroeconomic fundamentals, such as bilateral trade, fiscal balance, inflation, GDP growth, and the current account balance, the results we obtain are largely insignificant, suggesting that US investors focus instead on financial market and political characteristics when investing in government bonds.

We perform several robustness checks in order to explore the sensitivity of the results with respect to changes in sample coverage and model specification. First, we exclude each country from the sample one-by-one and re-estimate the model. The results prove to be relatively robust, even though the level of significance varies slightly for some political variables. Second, we exclude single control variables one-by-one and yet again the results are qualitatively similar.

<Insert Table 1 around here>

<Insert Table 2 around here>

\section{Study of interactions}


Given the large heterogeneity of countries in the sample, a more nuanced empirical analysis is required in order to analyze the impact of political factors on US government bond holdings. We expect a more pronounced role of political factors conditional on the respective country's structural characteristics. Plausibly, the US investor's assessment of political risks varies along several structural dimensions. For instance, investors may place a different amount of emphasis on political factors in countries with poor institutions compared to those countries where institutions are highly developed. Alternatively, political factors may become key to investors if there are general concerns about government solvency. Following this line of reasoning, we differentiate the analysis with respect to several dimensions. In addition to investigating the average effects of political factors on US bond holdings in the baseline regressions, we now use interaction models to explore the role of several structural channels which we expect to have an influence on how US investors assess political factors.

First, we investigate the role of institutions and governance. We expect the impact of political factors on US bond holdings to differ between countries with sound institutions and those with poor institutions. More precisely, we think of institutions as being the prerequisite for the effective implementation of economic policies. In countries where sound institutions would alleviate implementation of policy changes, US investors may dislike political constraints which have the potential to hinder the government from passing bills on economic reforms of consolidation packages. In countries with poor institutions, where implementation of policy change is inefficient anyway, US investors may acknowledge political constraints which at least help to reduce the probability of sovereign default. Second, we expect indicators of sovereign solvency to influence the extent to which US investors take political factors into account. As suggested by the theory on credible commitment and policy stability, US investors may prefer a higher degree of political constraints if a deviation from the status quo policy entails a potential default on sovereign debt. Third, we test how results differ with respect to political regimes. Political factors may matter differently in countries where democracy is more 
institutionalized compared to less democratic regimes. In highly democratic regimes, US investors may appreciate strong governments because political openness and competition will increase the likelihood of stable policy outcomes. Ultimately, we analyze if investors judge political factors differently in presidential and parliamentary regimes.

\subsection{Conditional Effects}

\subsubsection{Institutions}

To investigate the interplay between political factors and institutions, we use the World Governance Indicators (WGI, Kaufmann et al. 2011). The WGI incorporate information about the rule of law, regulatory quality, government effectiveness, voice and accountability, control of corruption and political stability. We compute average scores with respect to these dimensions and split the sample into countries with relatively "sound" institutions (with institutional quality above the sample median) and countries with relatively "poor" institutions (with institutional quality below the sample median). We then estimate interaction models in which the political factor is interacted with a country sample dummy, allowing us to study the conditional effect of political factors on US government bond holdings. The regression results in Table 3 presenting the marginal effects draw different pictures depending on the quality of institutions. Apart from the all-houses dummy, which is positively significant for both groups, the relative importance of political factors differs substantially. In countries with good institutions, US investors appreciate a low degree of checks and balances and a low level of polarization between the governing party and the legislature. The size of the effects is economically significant: For instance, given an increase in the number of checks by one, US government bond holdings are predicted to decline by 19\%. Overall, US government bond holdings are higher when political constraints decrease - but only for countries with sound institutions. For countries with poor institutional quality, US government bond holdings do not respond significantly to political constraints. Since good institutions are a precondition for the consolidation of public finances (efficient tax regimes, control over expenditures) or to 
implement economic reforms, the political power to initiate such policies is key. For countries with poor institutions, US investors do not appear to be convinced that fiscal consolidations or reforms can be implemented in practice. Political constraints are therefore not considered a relevant determinant for bond holdings in countries with poor institutions.

Further differences emerge when investigating the impact of variables related to elections and stability. In countries with sound institutions, the government bond holdings of US investors show a reduction during election years and years preceding an election. Additionally, turnover in key political players, measured by the drop in veto players, negatively affects US government bond holdings. On the other hand, in countries with poor institutions, these factors do not have any significant effect. US investors do not seem to believe that political business cycles have any long-run impact on sovereign solvency given that institutional quality is insufficient. US investors seem instead to appreciate an experienced chief executive, as indicated by the positive coefficient on executive tenure.

The results also indicate that government ideology plays a significant role in countries with poor institutions: US investors hold less government bonds if a right-wing government is in power, while a left-wing government coming into power does not significantly affect bond holdings.

In general, the findings illustrate that US investors place an emphasis on the role of institutions in the sense that they are an important prerequisite for changes in political factors, thus having a practical effect on government bond performance. In countries with sound institutions, US investors appreciate a strong government, which does not face many checks and does not have a polarizing opposition. These results are consistent with the notion that a government's ability to credibly provide the prospect of debt repayment increases with institutional quality. Accordingly, the combination of a strong government and sound institutions constitute the best environment for government bond investments. Similarly, US investors seem to acknowledge that changes in key political players - e.g., caused by elections 
- may entail significant changes because sound institutions promote the effective implementation of new policies pushed by a newly elected government. Investors therefore respond to the political cycle and reduce bond holdings in times of political uncertainty. On the contrary, in countries with weak institutions, investors do not seem to have a significant reaction to a changing level of political constraints on the government. Likewise, in these countries investors do not appear to believe that the outcome of elections or a change in veto players can lead to a change in government bond performance if the prevailing institutional quality is not sufficient to promote real change.

\section{<Insert Table 3 around here>}

\subsubsection{Sovereign Debt}

Another structural channel that may shape the impact of political factors on US government bond holdings is the level of public indebtedness. Again, we use interaction models to analyze the impact of political factors for countries with high versus low gross government debt to GDP. We consider a country with a government debt level above (below) the sample median of $45 \%$ of GDP to be a high debt (low debt) country. The results in Table 4 illustrate that the role of political constraints is quite similar across countries with different levels of debt. In order to reduce public indebtedness, implementing economic reforms or fiscal consolidation measures is easier for relatively unconstrained governments. As a counter hypothesis, the theory on credible commitment suggests that investors may demand a higher level of political constraints in order to prevent sovereign default in countries with a high level of debt. Overall, we find that US investors appreciate a low level of political constraints for both country sets. For high and low debt countries, the coefficient on checks and balances and the degree of polarization are negatively associated with government bond holdings. Furthermore, governments controlling all relevant houses of the legislature attract relatively more investments. Investors appear to appreciate a high feasibility of policy change as the government is able to implement the necessary policies to handle the debt burden. Given how 
successful many countries - including the US - are in managing high government debt levels, this result is not too surprising. Put differently, US investors do not seem to derive an immediate risk of default from the level of government debt alone.

The estimation results further illustrate that government bond holdings in high-debt countries are sensitive to political uncertainty and instability caused by elections or the drop in veto players. Apparently, investors envisage increased uncertainty in how a new (or modified) government will handle the burden of high debt. Furthermore, party preferences seem to be a concern to US investors in highly-indebted countries: Both left-wing and right-wing governing parties attract significantly less US investment compared to centrist governing parties.

Contrary to high debt countries, political factors related to elections, stability and ideology do not play any significant role in low debt countries. Plausibly, investors place less weight on the assessment of these political factors when sovereign indebtedness is low and a sovereign default is unlikely.

\section{<Insert Table 4 around here>}

\subsubsection{Sovereign Default Risk}

\section{Credit rating}

In this section, we consider the level of sovereign default risk, which is measured using sovereign credit ratings. While the level of public debt, as used in the previous section, also measures sovereign solvency, investors' assessment of debt sustainability is very different for emerging markets and developed countries. Thus, in order to analyze the impact of political factors on US bond holdings for high risk vs. low risk countries, we turn to sovereign credit ratings as they are a much better indicator of sovereign default risk than the public debt level. We consider the credit ratings of S\&P, Moody's and Fitch, where a credit rating below (equal to/above) BB- indicates a high (low to moderate) credit risk country. Rating agencies assess countries which are beyond this threshold as being associated with high credit risk, close to 
default, or even in technical or actual default (compare Afonso et al., 2012). Table 5 presents the estimation results. What stands out here is that in high risk countries, bond holdings are now positively associated with the level of polarization, while the coefficient on number of checks becomes statistically insignificant. In the event that a rating agency assigns a bad credit rating, US investors appear to be less confident that the government of the country in question is willing to implement the necessary reforms, but is instead inclined to address fiscal problems by defaulting on sovereign debt. Since political constraints (such as those measured by checks and polarization) make sovereign default more difficult for the government, US investors invest more in regimes where such constraints exist. In low risk countries, there is evidence that bondholders prefer a lower degree of political constraints: The variables checks and polarization are negatively associated with bond holdings, while the control of all houses has a positive effect. US investors prefer unconstrained governments in low risk regimes, where policy change is feasible and default risk is not an important issue. In countries with a poor credit rating, we additionally observe that US bond holdings are significantly lower in years where a newly elected government assumes power. What is more, the coefficient on the drop in veto players is highly statistically significant and several times larger than for low risk countries. Plausibly, US investors perceive political change in the context of high credit risk as a substantial risk factor and decrease bond holdings accordingly.

<Insert Table 5 around here>

\section{Past sovereign default}

In addition to the current level of default risk analyzed above, we investigate whether US investors assess political factors differently in countries with respect to repayment history. Taking the observation of serial defaults into account, we would expect that US investors anticipate higher levels of politically determined sovereign default risk if the country in 
question has defaulted on its debt in the past. ${ }^{8} \mathrm{We}$ use the sovereign debt crisis indicator of Laeven and Valencia (2012) $)^{9}$ to construct a dummy variable taking the value of one if a country has experienced a default on sovereign debt in the past 20 years, and 0 otherwise. Table 6 presents the marginal effects of political factors conditional on past default. The results portray a similar picture to those before, indicating that US investors assess political factors in countries with a history of default similar to countries with a poor credit rating. Indeed, in countries with a history of default, Herfindahl government negatively affects bond holdings, indicating that the concentration of power in one single government party deters government bond investments if the country has defaulted in the past. For countries without past sovereign defaults, US investors appreciate the absence of political constraints since they do not consider them to be an important commitment device against possible politically induced sovereign defaults.

The results indicate that in countries with considerable sovereign default risk, as countries with a high credit risk rating or countries which have defaulted in the past, US investors do not appreciate low levels of political constraints. On the contrary, the results reveal some tendency towards US investors holding more bonds if the government is politically constrained, putting it in a better position to credibly commit to debt repayment.

In countries with low levels of sovereign default risk, credible commitment is less important to US investors, who, in this case, prefer relatively unconstrained governments which are able to enforce the implementation of fiscal consolidation and economic reforms.

\section{<Insert Table 6 around here>}

\subsubsection{Political System}

\section{Democracy}

\footnotetext{
${ }^{8}$ Reinhart et al. (2003) demonstrate that past defaults of countries can be associated with a higher probability of future defaults: Countries which have serially defaulted seem to be more vulnerable in the sense that they have an increased risk of default, even at relatively low debt levels.

${ }^{9}$ For recent years, we use information from sovereign credit ratings.
} 
In this section, we test the implications of different political systems for the relevance of political factors. First, we differentiate between the quality of democratic institutions using the POLITY2 index from the Polity4 database. The POLITY2-variable captures several dimensions of democracy such as the degree of political participation, the openness and competitiveness of executive recruitment and constraints on the chief executive. By weighting these different aspects, countries are classified on a scale between strongly autocratic and strongly democratic. We define a country as being highly democratic if the POLITY2 score is equal to or greater than nine (the sample median). ${ }^{10}$ The results in Table 7 show that, given countries are highly democratic, a low level of political constraints (as indicated by a low level of checks and polarization) is preferred by US investors: Control of all houses has a positive effect, whereas the number of checks is negatively correlated with bond holdings. In addition, a low degree of polarization is favored. These results indicate that US investors trust governments in democratic regimes insofar as they appreciate a high feasibility of implementing necessary adjustment policies in order to ensure fiscal sustainability. On the other hand, in less democratic regimes, only the control of all houses is positively associated with bond holdings.

The drop in veto players is negatively related to bond holdings, both in highly democratic and less democratic regimes. Apparently, US investors perceive the degree of fluctuation in veto players as a sign of instability irrespective of the development of democratic institutions.

In line with the results for countries with sound institutions, the event of an election in highly democratic regimes is associated with significantly less government bond holdings. This result is consistent with the notion that in democratic regimes, the event of an election is the main mechanism through which major shifts in economic policy are initiated. On the other hand, in less democratic regimes, bond holdings do not significantly respond to elections. US investors do not seem to believe that elections in less democratic regimes could have any

${ }^{10}$ For instance, as of 2011, the UK achieves a polity score of 10 and is thus considered a highly democratic country, whereas Argentina has a score of 8 and is classified as a less-democratic country. 
significant effect on government bond performance. Instead, investors appear to identify the head of government as the crucial factor in less democratic regimes: A high tenure is associated with significantly more bond holdings.

\section{<Insert Table 7 around here>}

\section{Parliamentary vs. Presidential regime}

In the next step, we investigate if the impact of political factors on US bond holdings differs depending on whether the political regime is parliamentary or presidential. As the results in Table 8 illustrate, the size of the coefficient on control of all houses is more than twice as large in presidential regimes as it is in parliamentary regimes, as well as being statistically significant, at the $1 \%$ level. Plausibly, the separation of powers in presidential regimes gives high prominence to the chief executive party's control of the legislature. This finding relates to the general criticism of presidential political regimes, where a political gridlock can arise whenever the president and legislative majority are from different parties. US investors seem to acknowledge this and prefer the governing party to control all houses of the legislature. In parliamentary regimes, there is a negative association between bond holdings and polarization and the number of checks. For presidential regimes, these factors are statistically insignificant. This result is plausible given that in parliamentary regimes, the number of checks and the level of polarization heavily depend on the number of parties which form the government coalition. That is, US investors monitor the composition of the government and prefer relatively homogenous coalition governments characterized by a low number of parties and a low degree of ideological polarization. Obviously, these aspects of political constraints do not matter in presidential regimes, where only the party of the chief executive controls the government.

Another difference to emerge is that elections are only associated with significantly less government bond holdings in parliamentary regimes. A possible explanation is that this result is driven by early elections, which frequently occur in parliamentary regimes as the legislature 
can typically be dissolved at any time. Assumedly, US investors respond more strongly to early elections than to those which are held at the originally scheduled time. Early elections seldom occur in presidential regimes, where elections are generally fixed.

For ideology, US investors seem to be more sensitive to changes in governing party ideology in parliamentary regimes: Both left-wing and right-wing governing parties are associated with more government bond holdings.

<Insert Table 8 around here>

\section{Concluding Remarks}

This paper has analyzed the influence of political factors on government bond holdings of US investors using annual panel data for 60 countries over the $2003-2013$ period. A key result is that political constraints on the government matter for US bond investors. Political constraints on the government - such as the presence of many veto players, a high level of polarization in the legislature, or a fractionalized government coalition - have two important implications for policy makers in times of fiscal stress. First, political constraints reduce the government's ability to make necessary decisions (such as implementing fiscal consolidation measures or economic reforms) since veto players within the political system (inside or outside of the government) can block such policies. On the contrary, political constraints may also enhance the credible commitment of the government and prevent a default on sovereign debt.

Our results also reveal how US investors in government bonds respond differently to political constraints, depending on the institutional backgrounds and solvency situations of the respective countries in the sample. We find that US investors prefer to invest in government bonds of countries with relatively unconstrained governments when domestic institutions are highly developed. Political constraints appear to become less important if the institutional quality is rather low. This is consistent with the notion that practical implementation of fiscal measures is only effective if the institutional framework guarantees an effective tax 
administration and control over public expenditures. US investors seem to acknowledge that unconstrained governments can only safeguard fiscal stability in countries with a strong institutional background and adjust their bond holdings accordingly. The general implication of this result is that governments faced with few political constraints can attract more investment in government bonds by improving their institutional framework.

Another major finding is that US investors respond to increased uncertainty about future economic policy by adjusting bond holdings in line with the political cycle: In an election year, investors hold significantly less government bonds. This result is stronger for countries with sound institutions but insignificant in a poor institutional environment. US investors seem to acknowledge that turnover in key political players may entail important changes, but only if sound institutions promote the effective implementation of new policies.

Furthermore, we find that the impact of political constraints is dependent on sovereign solvency. In times of fiscal stress, the domestic government may choose to default on sovereign debt, which is particularly likely in political environments with weak political constraints. We find that for countries with a poor credit rating or a history of sovereign default, US investors do not seem to prefer governments facing a low level of political constraints. There are even some indications that they tend to invest in political regimes where strong political constraints on the government act as a commitment device for the repayment of sovereign debt. Thus, a country with sovereign solvency problems may attract government bond investments by improving on its system of checks and balances and ensuring a sufficient level of political constraints. 

(1)
(2)
(3)
(4)
(5)

\begin{tabular}{|c|c|c|c|c|c|}
\hline Checks & $\begin{array}{c}-0.164 * * * \\
{[0.002]}\end{array}$ & & & & \\
\hline Majority & & $\begin{array}{c}0.004 \\
{[0.183]}\end{array}$ & & & \\
\hline Herfindahl government & & & $\begin{array}{c}0.001 \\
{[0.831]}\end{array}$ & & \\
\hline Control of all houses & & & & $\begin{array}{c}0.345 * * * \\
{[0.000]}\end{array}$ & \\
\hline Polarization & & & & & $\begin{array}{c}-0.106^{* * * *} \\
{[0.001]}\end{array}$ \\
\hline Ln(government debt) & $\begin{array}{c}0.757 * * * \\
{[0.000]}\end{array}$ & $\begin{array}{c}0.820 * * * \\
{[0.000]}\end{array}$ & $\begin{array}{c}0.789 * * * \\
{[0.000]}\end{array}$ & $\begin{array}{c}0.858^{* * * *} \\
{[0.000]}\end{array}$ & $\begin{array}{c}0.931 * * * \\
{[0.000]}\end{array}$ \\
\hline Government bond return & $\begin{array}{c}1.950 * * * \\
{[0.002]}\end{array}$ & $\begin{array}{c}2.067 * * * \\
{[0.000]}\end{array}$ & $\begin{array}{c}1.988 * * * \\
{[0.001]}\end{array}$ & $\begin{array}{c}2.143 * * * \\
{[0.000]}\end{array}$ & $\begin{array}{c}1.911 * * * \\
{[0.000]}\end{array}$ \\
\hline Exchange rate & $\begin{array}{c}0.782 \\
{[0.315]}\end{array}$ & $\begin{array}{c}0.696 \\
{[0.268]}\end{array}$ & $\begin{array}{c}0.839 \\
{[0.177]}\end{array}$ & $\begin{array}{c}0.625 \\
{[0.242]}\end{array}$ & $\begin{array}{c}0.700 \\
{[0.261]}\end{array}$ \\
\hline Bond yield & $\begin{array}{c}-0.014 \\
{[0.247]}\end{array}$ & $\begin{array}{c}-0.010 \\
{[0.347]}\end{array}$ & $\begin{array}{c}-0.008 \\
{[0.457]}\end{array}$ & $\begin{array}{c}-0.003 \\
{[0.824]}\end{array}$ & $\begin{array}{l}-0.015 \\
{[0.140]}\end{array}$ \\
\hline Equity return & $\begin{array}{c}-0.194 \\
{[0.452]}\end{array}$ & $\begin{array}{l}-0.407^{*} \\
{[0.093]}\end{array}$ & $\begin{array}{l}-0.414^{*} \\
{[0.090]}\end{array}$ & $\begin{array}{c}-0.318 \\
{[0.203]}\end{array}$ & $\begin{array}{c}-0.332 \\
{[0.167]}\end{array}$ \\
\hline Bond return correlation & $\begin{array}{c}-0.119 \\
{[0.567]}\end{array}$ & $\begin{array}{l}-0.101 \\
{[0.628]}\end{array}$ & $\begin{array}{c}-0.088 \\
{[0.670]}\end{array}$ & $\begin{array}{c}-0.144 \\
{[0.453]}\end{array}$ & $\begin{array}{l}-0.011 \\
{[0.961]}\end{array}$ \\
\hline Sd(equity return) & $\begin{array}{c}-0.016 \\
{[0.832]}\end{array}$ & $\begin{array}{l}-0.049 \\
{[0.513]}\end{array}$ & $\begin{array}{l}-0.051 \\
{[0.533]}\end{array}$ & $\begin{array}{l}-0.054 \\
{[0.515]}\end{array}$ & $\begin{array}{l}-0.077 \\
{[0.371]}\end{array}$ \\
\hline Sd(bond return) & $\begin{array}{c}0.425 * * * \\
{[0.008]}\end{array}$ & $\begin{array}{c}0.310^{* *} \\
{[0.023]}\end{array}$ & $\begin{array}{c}0.299 * * \\
{[0.025]}\end{array}$ & $\begin{array}{c}0.249^{* *} \\
{[0.045]}\end{array}$ & $\begin{array}{c}0.300^{* *} \\
{[0.045]}\end{array}$ \\
\hline Sd(exchange rate) & $\begin{array}{c}-0.375 \\
{[0.149]}\end{array}$ & $\begin{array}{l}-0.179 \\
{[0.159]}\end{array}$ & $\begin{array}{l}-0.191 \\
{[0.168]}\end{array}$ & $\begin{array}{l}-0.219^{*} \\
{[0.074]}\end{array}$ & $\begin{array}{l}-0.121 \\
{[0.356]}\end{array}$ \\
\hline High credit risk & $\begin{array}{l}-0.386 \\
{[0.112]}\end{array}$ & $\begin{array}{l}-0.363 \\
{[0.151]}\end{array}$ & $\begin{array}{l}-0.402 \\
{[0.132]}\end{array}$ & $\begin{array}{l}-0.247 \\
{[0.336]}\end{array}$ & $\begin{array}{l}-0.071 \\
{[0.757]}\end{array}$ \\
\hline Bilateral trade & $\begin{array}{c}0.182 \\
{[0.369]}\end{array}$ & $\begin{array}{c}0.217 \\
{[0.183]}\end{array}$ & $\begin{array}{c}0.228 \\
{[0.168]}\end{array}$ & $\begin{array}{c}0.144 \\
{[0.140]}\end{array}$ & $\begin{array}{c}0.200 \\
{[0.294]}\end{array}$ \\
\hline Capital account openness & $\begin{array}{c}0.001 \\
{[0.861]}\end{array}$ & $\begin{array}{c}0.002 \\
{[0.696]}\end{array}$ & $\begin{array}{c}0.002 \\
{[0.683]}\end{array}$ & $\begin{array}{c}0.002 \\
{[0.647]}\end{array}$ & $\begin{array}{c}0.005 \\
{[0.359]}\end{array}$ \\
\hline Inflation & $\begin{array}{l}-0.012 \\
{[0.378]}\end{array}$ & $\begin{array}{c}-0.016 \\
{[0.259]}\end{array}$ & $\begin{array}{c}-0.016 \\
{[0.247]}\end{array}$ & $\begin{array}{c}-0.027^{*} \\
{[0.054]}\end{array}$ & $\begin{array}{l}-0.010 \\
{[0.441]}\end{array}$ \\
\hline GDP growth & $\begin{array}{c}-0.014 * * \\
{[0.049]}\end{array}$ & $\begin{array}{c}-0.014 * * \\
{[0.042]}\end{array}$ & $\begin{array}{l}-0.012 \\
{[0.112]}\end{array}$ & $\begin{array}{c}-0.018 * * * \\
{[0.004]}\end{array}$ & $\begin{array}{c}-0.021 * * * \\
{[0.009]}\end{array}$ \\
\hline Current account & $\begin{array}{c}0.014 \\
{[0.363]}\end{array}$ & $\begin{array}{c}0.007 \\
{[0.627]}\end{array}$ & $\begin{array}{c}0.009 \\
{[0.546]}\end{array}$ & $\begin{array}{c}0.001 \\
{[0.950]}\end{array}$ & $\begin{array}{c}0.005 \\
{[0.768]}\end{array}$ \\
\hline Fiscal balance & $\begin{array}{c}0.036^{* *} \\
{[0.032]}\end{array}$ & $\begin{array}{c}0.028 \\
{[0.115]}\end{array}$ & $\begin{array}{c}0.024 \\
{[0.154]}\end{array}$ & $\begin{array}{c}0.024 \\
{[0.188]}\end{array}$ & $\begin{array}{l}0.031^{*} \\
{[0.071]}\end{array}$ \\
\hline Observations & 581 & 588 & 588 & 560 & 494 \\
\hline Number of countries & 60 & 60 & 60 & 59 & 54 \\
\hline Wald Chi2 & 0.000 & 0.000 & 0.000 & 0.000 & 0.000 \\
\hline R-squared & 0.376 & 0.407 & 0.415 & 0.401 & 0.423 \\
\hline
\end{tabular}

Note: this table reports PPML estimation results of end-year US government bond holdings on indicators of political constraints plus a range of macroeconomic and financial market indicators. Country and time fixed effects are included, but not reported. p-values (in parentheses) are based on robust standard errors clustered at the country level. *, **, and *** indicates the $10 \%, 5 \%$, and $1 \%$ level of significance, respectively. 
(1)

(2)

(3)

(4)

(5)

(6)

(7)

\begin{tabular}{|c|c|c|c|c|c|c|c|}
\hline Election year & $\begin{array}{l}-0.085^{*} \\
{[0.061]}\end{array}$ & & & & & & \\
\hline Pre-election year & $\begin{array}{l}-0.063 \\
{[0.130]}\end{array}$ & & & & & & \\
\hline New elected executive & & $\begin{array}{l}-0.021 \\
{[0.659]}\end{array}$ & & & & & \\
\hline New elected gov. party & & & $\begin{array}{c}-0.041 \\
{[0.558]}\end{array}$ & & & & \\
\hline Executive tenure & & & & $\begin{array}{c}0.001 \\
{[0.945]}\end{array}$ & & & \\
\hline Government party tenure & & & & & $\begin{array}{l}-0.001 \\
{[0.919]}\end{array}$ & & \\
\hline Drop in veto players & & & & & & $\begin{array}{c}-0.151^{* *} \\
{[0.012]}\end{array}$ & \\
\hline Left-wing government & & & & & & & $\begin{array}{c}-0.271 \\
{[0.264]}\end{array}$ \\
\hline Right-wing government & & & & & & & $\begin{array}{l}-0.251 \\
{[0.292]}\end{array}$ \\
\hline $\operatorname{Ln}($ government debt) & $\begin{array}{c}0.778 * * * \\
{[0.000]}\end{array}$ & $\begin{array}{c}0.788 * * * \\
{[0.000]}\end{array}$ & $\begin{array}{c}0.796 * * * \\
{[0.000]}\end{array}$ & $\begin{array}{c}0.788 * * * \\
{[0.000]}\end{array}$ & $\begin{array}{c}0.794 * * * \\
{[0.000]}\end{array}$ & $\begin{array}{c}0.774 * * * \\
{[0.000]}\end{array}$ & $\begin{array}{c}0.889 * * * \\
{[0.000]}\end{array}$ \\
\hline Government bond return & $\begin{array}{c}2.011 * * * \\
{[0.001]}\end{array}$ & $\begin{array}{c}2.003 * * * \\
{[0.001]}\end{array}$ & $\begin{array}{c}1.849^{* * *} * \\
{[0.001]}\end{array}$ & $\begin{array}{c}2.003 * * * \\
{[0.000]}\end{array}$ & $\begin{array}{c}1.867 * * * \\
{[0.001]}\end{array}$ & $\begin{array}{c}1.915 * * * \\
{[0.001]}\end{array}$ & $\begin{array}{c}1.659 * * * \\
{[0.005]}\end{array}$ \\
\hline Exchange rate & $\begin{array}{c}0.867 \\
{[0.176]}\end{array}$ & $\begin{array}{c}0.832 \\
{[0.194]}\end{array}$ & $\begin{array}{c}0.900 \\
{[0.164]}\end{array}$ & $\begin{array}{c}0.829 \\
{[0.196]}\end{array}$ & $\begin{array}{c}0.935 \\
{[0.138]}\end{array}$ & $\begin{array}{c}0.791 \\
{[0.223]}\end{array}$ & $\begin{array}{c}0.648 \\
{[0.513]}\end{array}$ \\
\hline Bond yield & $\begin{array}{c}-0.008 \\
{[0.472]}\end{array}$ & $\begin{array}{c}-0.008 \\
{[0.470]}\end{array}$ & $\begin{array}{l}-0.008 \\
{[0.475]}\end{array}$ & $\begin{array}{l}-0.008 \\
{[0.459]}\end{array}$ & $\begin{array}{l}-0.009 \\
{[0.460]}\end{array}$ & $\begin{array}{l}-0.006 \\
{[0.587]}\end{array}$ & $\begin{array}{l}-0.015 \\
{[0.250]}\end{array}$ \\
\hline Equity return & $\begin{array}{l}-0.404^{*} \\
{[0.086]}\end{array}$ & $\begin{array}{l}-0.432 * \\
{[0.076]}\end{array}$ & $\begin{array}{c}-0.512 * * \\
{[0.030]}\end{array}$ & $\begin{array}{l}-0.419^{*} \\
{[0.086]}\end{array}$ & $\begin{array}{c}-0.512 * * \\
{[0.029]}\end{array}$ & $\begin{array}{l}-0.436^{*} \\
{[0.059]}\end{array}$ & $\begin{array}{c}-0.825^{* *} \\
{[0.021]}\end{array}$ \\
\hline Bond return correlation & $\begin{array}{l}-0.097 \\
{[0.638]}\end{array}$ & $\begin{array}{l}-0.087 \\
{[0.672]}\end{array}$ & $\begin{array}{c}-0.079 \\
{[0.708]}\end{array}$ & $\begin{array}{l}-0.087 \\
{[0.677]}\end{array}$ & $\begin{array}{l}-0.078 \\
{[0.704]}\end{array}$ & $\begin{array}{l}-0.058 \\
{[0.777]}\end{array}$ & $\begin{array}{c}0.135 \\
{[0.607]}\end{array}$ \\
\hline $\operatorname{Sd}($ equity return) & $\begin{array}{l}-0.060 \\
{[0.422]}\end{array}$ & $\begin{array}{l}-0.056 \\
{[0.467]}\end{array}$ & $\begin{array}{l}-0.126 \\
{[0.121]}\end{array}$ & $\begin{array}{l}-0.056 \\
{[0.468]}\end{array}$ & $\begin{array}{l}-0.122 \\
{[0.121]}\end{array}$ & $\begin{array}{l}-0.056 \\
{[0.472]}\end{array}$ & $\begin{array}{l}-0.158 \\
{[0.111]}\end{array}$ \\
\hline $\mathrm{Sd}$ (bond return) & $\begin{array}{l}0.302 * * \\
{[0.019]}\end{array}$ & $\begin{array}{c}0.297 * * \\
{[0.029]}\end{array}$ & $\begin{array}{l}0.222^{*} \\
{[0.075]}\end{array}$ & $\begin{array}{c}0.298 * * \\
{[0.024]}\end{array}$ & $\begin{array}{l}0.218^{*} \\
{[0.064]}\end{array}$ & $\begin{array}{c}0.280 * * \\
{[0.034]}\end{array}$ & $\begin{array}{c}0.166 \\
{[0.358]}\end{array}$ \\
\hline Sd(exchange rate) & $\begin{array}{l}-0.166 \\
{[0.185]}\end{array}$ & $\begin{array}{c}-0.184 \\
{[0.152]}\end{array}$ & $\begin{array}{l}-0.070 \\
{[0.549]}\end{array}$ & $\begin{array}{c}-0.183 \\
{[0.151]}\end{array}$ & $\begin{array}{l}-0.075 \\
{[0.503]}\end{array}$ & $\begin{array}{l}-0.189 \\
{[0.153]}\end{array}$ & $\begin{array}{l}-0.078 \\
{[0.734]}\end{array}$ \\
\hline High credit risk & $\begin{array}{l}-0.423^{*} \\
{[0.099]}\end{array}$ & $\begin{array}{c}-0.399 \\
{[0.134]}\end{array}$ & $\begin{array}{c}-0.338 \\
{[0.214]}\end{array}$ & $\begin{array}{c}-0.398 \\
{[0.142]}\end{array}$ & $\begin{array}{l}-0.346 \\
{[0.218]}\end{array}$ & $\begin{array}{l}-0.391 \\
{[0.135]}\end{array}$ & $\begin{array}{c}0.026 \\
{[0.883]}\end{array}$ \\
\hline Bilateral trade & $\begin{array}{c}0.265 \\
{[0.115]}\end{array}$ & $\begin{array}{c}0.226 \\
{[0.189]}\end{array}$ & $\begin{array}{l}0.267^{*} \\
{[0.088]}\end{array}$ & $\begin{array}{c}0.224 \\
{[0.197]}\end{array}$ & $\begin{array}{c}0.264 \\
{[0.114]}\end{array}$ & $\begin{array}{c}0.226 \\
{[0.187]}\end{array}$ & $\begin{array}{c}0.187 \\
{[0.237]}\end{array}$ \\
\hline Capital account openness & $\begin{array}{c}0.002 \\
{[0.697]}\end{array}$ & $\begin{array}{c}0.002 \\
{[0.699]}\end{array}$ & $\begin{array}{c}0.003 \\
{[0.507]}\end{array}$ & $\begin{array}{c}0.002 \\
{[0.710]}\end{array}$ & $\begin{array}{c}0.003 \\
{[0.509]}\end{array}$ & $\begin{array}{c}0.002 \\
{[0.708]}\end{array}$ & $\begin{array}{c}0.008 \\
{[0.342]}\end{array}$ \\
\hline Inflation & $\begin{array}{l}-0.016 \\
{[0.235]}\end{array}$ & $\begin{array}{l}-0.016 \\
{[0.244]}\end{array}$ & $\begin{array}{l}-0.020 \\
{[0.124]}\end{array}$ & $\begin{array}{l}-0.016 \\
{[0.238]}\end{array}$ & $\begin{array}{l}-0.020 \\
{[0.122]}\end{array}$ & $\begin{array}{l}-0.016 \\
{[0.247]}\end{array}$ & $\begin{array}{c}-0.015 \\
{[0.363]}\end{array}$ \\
\hline GDP growth & $\begin{array}{c}-0.012 \\
{[0.104]}\end{array}$ & $\begin{array}{l}-0.012 \\
{[0.104]}\end{array}$ & $\begin{array}{c}-0.019 * * \\
{[0.013]}\end{array}$ & $\begin{array}{l}-0.012 * \\
{[0.100]}\end{array}$ & $\begin{array}{c}-0.018 * * \\
{[0.012]}\end{array}$ & $\begin{array}{l}-0.013^{*} \\
{[0.087]}\end{array}$ & $\begin{array}{l}-0.014 \\
{[0.279]}\end{array}$ \\
\hline Current account & $\begin{array}{c}0.011 \\
{[0.478]}\end{array}$ & $\begin{array}{c}0.010 \\
{[0.546]}\end{array}$ & $\begin{array}{c}0.004 \\
{[0.802]}\end{array}$ & $\begin{array}{c}0.009 \\
{[0.580]}\end{array}$ & $\begin{array}{c}0.003 \\
{[0.837]}\end{array}$ & $\begin{array}{c}0.011 \\
{[0.482]}\end{array}$ & $\begin{array}{c}0.021 \\
{[0.308]}\end{array}$ \\
\hline Fiscal balance & $\begin{array}{c}0.024 \\
{[0.134]}\end{array}$ & $\begin{array}{c}0.024 \\
{[0.155]}\end{array}$ & $\begin{array}{c}0.021 \\
{[0.226]}\end{array}$ & $\begin{array}{c}0.024 \\
{[0.134]}\end{array}$ & $\begin{array}{c}0.021 \\
{[0.183]}\end{array}$ & $\begin{array}{c}0.022 \\
{[0.204]}\end{array}$ & $\begin{array}{c}0.015 \\
{[0.385]}\end{array}$ \\
\hline Observations & 589 & 587 & 529 & 587 & 529 & 586 & 408 \\
\hline Number of countries & 60 & 60 & 56 & 60 & 56 & 60 & 45 \\
\hline Wald Chi2 & 0.000 & 0.000 & 0.000 & 0.000 & 0.000 & 0.000 & 0.000 \\
\hline R-squared & 0.418 & 0.414 & 0.434 & 0.414 & 0.435 & 0.414 & 0.384 \\
\hline
\end{tabular}


Table 3: The effect of political factors conditional on the quality of institutions

\begin{tabular}{|c|c|c|c|}
\hline & Unconditional & Sound institutions & Poor institutions \\
\hline \multicolumn{4}{|l|}{ Political constraints } \\
\hline \multirow[t]{2}{*}{ Checks } & $-0.164 * * *$ & $-0.188 * * *$ & -0.005 \\
\hline & {$[0.002]$} & {$[0.001]$} & {$[0.964]$} \\
\hline \multirow[t]{2}{*}{ Majority } & 0.004 & 0.004 & 0.004 \\
\hline & {$[0.183]$} & {$[0.305]$} & {$[0.426]$} \\
\hline \multirow[t]{2}{*}{ Herfindahl government } & 0.001 & 0.003 & -0.005 \\
\hline & {$[0.831]$} & {$[0.439]$} & {$[0.446]$} \\
\hline \multirow[t]{2}{*}{ Control of all houses } & $0.345^{* * *}$ & $0.249 * *$ & $0.651 * * *$ \\
\hline & {$[0.000]$} & {$[0.023]$} & {$[0.000]$} \\
\hline \multirow[t]{2}{*}{ Polarization } & $-0.106 * * *$ & $-0.105 * * *$ & -0.140 \\
\hline & {$[0.001]$} & {$[0.003]$} & {$[0.400]$} \\
\hline \multicolumn{4}{|l|}{ Elections and stability } \\
\hline \multirow[t]{2}{*}{ Election year } & $-0.085 *$ & $-0.116^{* *}$ & 0.022 \\
\hline & {$[0.061]$} & [0.029] & {$[0.764]$} \\
\hline \multirow[t]{2}{*}{ Pre-election year } & -0.063 & $-0.089 *$ & 0.010 \\
\hline & {$[0.130]$} & {$[0.073]$} & {$[0.888]$} \\
\hline \multirow[t]{2}{*}{ New elected executive } & -0.021 & -0.040 & 0.043 \\
\hline & [0.659] & {$[0.410]$} & {$[0.633]$} \\
\hline \multirow[t]{2}{*}{ New elected gov. party } & -0.041 & -0.086 & 0.165 \\
\hline & {$[0.558]$} & [0.184] & {$[0.233]$} \\
\hline \multirow[t]{2}{*}{ Executive tenure } & 0.001 & -0.014 & $0.038 * * *$ \\
\hline & {$[0.945]$} & {$[0.295]$} & {$[0.001]$} \\
\hline \multirow[t]{2}{*}{ Government party tenure } & -0.001 & -0.001 & 0.000 \\
\hline & [0.919] & [0.904] & [0.994] \\
\hline \multirow[t]{2}{*}{ Drop in veto players } & $-0.151 * *$ & $-0.140 * *$ & -0.211 \\
\hline & {$[0.012]$} & {$[0.041]$} & {$[0.171]$} \\
\hline \multicolumn{4}{|l|}{ Ideology } \\
\hline \multirow[t]{2}{*}{ Left-wing government } & -0.271 & -0.096 & -0.022 \\
\hline & {$[0.264]$} & {$[0.820]$} & [0.906] \\
\hline \multirow[t]{2}{*}{ Right-wing government } & -0.251 & -0.061 & $-0.627 * * *$ \\
\hline & [0.292] & {$[0.885]$} & {$[0.000]$} \\
\hline
\end{tabular}

Note: this table reports PPML estimation results of the marginal effects of political variables on end-year US government bond holdings conditional on the quality of institutions. Countries with a World Governance Indicators (WGI) score above (below) the sample median are defined as good (poor) institution countries. Each specification controls for the macroeconomic and financial market indicators reported in the baseline regressions in Table 1 . The results for the control variables are available upon request. Country and time fixed effects are included, but not reported. p-values (in parentheses) are based on robust standard errors clustered at the country level. *, **, and *** indicates the $10 \%$, $5 \%$, and $1 \%$ level of significance, respectively. 
Table 4: The effect of political factors conditional on the level of government debt

\begin{tabular}{|c|c|c|c|}
\hline & Unconditional & High debt & Low debt \\
\hline \multicolumn{4}{|l|}{ Political constraints } \\
\hline \multirow[t]{2}{*}{ Checks } & $-0.164 * * *$ & $-0.166 * * *$ & $-0.145 * *$ \\
\hline & {$[0.002]$} & {$[0.005]$} & {$[0.040]$} \\
\hline \multirow[t]{2}{*}{ Majority } & 0.004 & 0.003 & 0.005 \\
\hline & {$[0.183]$} & [0.312] & [0.149] \\
\hline \multirow[t]{2}{*}{ Herfindahl government } & 0.001 & 0.003 & -0.003 \\
\hline & {$[0.831]$} & {$[0.410]$} & {$[0.494]$} \\
\hline \multirow[t]{2}{*}{ Control of all houses } & $0.345 * * *$ & $0.294 * * *$ & $0.487 * * *$ \\
\hline & {$[0.000]$} & {$[0.001]$} & {$[0.000]$} \\
\hline \multirow[t]{2}{*}{ Polarization } & $-0.106 * * *$ & $-0.091 * *$ & $-0.167 * *$ \\
\hline & {$[0.001]$} & {$[0.012]$} & {$[0.031]$} \\
\hline \multicolumn{4}{|l|}{ Elections and stability } \\
\hline \multirow[t]{2}{*}{ Election year } & $-0.085^{*}$ & $-0.114 * *$ & -0.016 \\
\hline & {$[0.061]$} & {$[0.042]$} & {$[0.828]$} \\
\hline \multirow[t]{2}{*}{ Pre-election year } & -0.063 & -0.061 & -0.077 \\
\hline & {$[0.130]$} & {$[0.220]$} & {$[0.185]$} \\
\hline \multirow[t]{2}{*}{ New elected executive } & -0.021 & -0.037 & 0.024 \\
\hline & [0.659] & {$[0.458]$} & {$[0.761]$} \\
\hline \multirow[t]{2}{*}{ New elected gov. party } & -0.041 & -0.086 & 0.068 \\
\hline & {$[0.558]$} & {$[0.254]$} & {$[0.515]$} \\
\hline \multirow[t]{2}{*}{ Executive tenure } & 0.001 & -0.007 & 0.018 \\
\hline & [0.945] & [0.609] & [0.349] \\
\hline \multirow[t]{2}{*}{ Government party tenure } & -0.001 & -0.001 & -0.007 \\
\hline & [0.919] & {$[0.921]$} & {$[0.606]$} \\
\hline \multirow[t]{2}{*}{ Drop in veto players } & $-0.151 * *$ & $-0.207 * * *$ & -0.021 \\
\hline & [0.012] & {$[0.001]$} & {$[0.876]$} \\
\hline \multicolumn{4}{|l|}{ Ideology } \\
\hline \multirow[t]{2}{*}{ Left-wing government } & -0.271 & $-0.548 * *$ & 0.047 \\
\hline & {$[0.264]$} & {$[0.036]$} & {$[0.832]$} \\
\hline \multirow[t]{2}{*}{ Right-wing government } & -0.251 & $-0.450 *$ & -0.155 \\
\hline & {$[0.292]$} & {$[0.091]$} & {$[0.527]$} \\
\hline
\end{tabular}

Note: this table reports PPML estimation results of the marginal effects of political variables on end-year US government bond holdings conditional on the level of debt. Countries with a gross government debt to GDP ratio above (below) 45\% are defined as high debt (low debt) countries. Each specification controls for the macroeconomic and financial market indicators reported in the baseline regressions in Table 1. The results for the control variables are available upon request. Country and time fixed effects are included, but not reported. p-values (in parentheses) are based on robust standard errors clustered at the country level. *,**, and $* * *$ indicates the $10 \%, 5 \%$, and $1 \%$ level of significance, respectively. 
Table 5: The effect of political factors conditional on sovereign credit rating

\begin{tabular}{|c|c|c|c|}
\hline & Unconditional & High risk & Low-moderate risk \\
\hline \multicolumn{4}{|l|}{ Political constraints } \\
\hline \multirow[t]{2}{*}{ Checks } & $-0.164 * * *$ & 0.061 & $-0.167 * * *$ \\
\hline & [0.002] & {$[0.588]$} & {$[0.002]$} \\
\hline \multirow[t]{2}{*}{ Majority } & 0.004 & 0.003 & 0.004 \\
\hline & {$[0.183]$} & {$[0.665]$} & {$[0.173]$} \\
\hline \multirow[t]{2}{*}{ Herfindahl government } & 0.001 & -0.008 & 0.001 \\
\hline & {$[0.831]$} & {$[0.128]$} & {$[0.757]$} \\
\hline \multirow[t]{2}{*}{ Control of all houses } & $0.345^{* * *}$ & $0.469 * *$ & $0.339 * * *$ \\
\hline & {$[0.000]$} & {$[0.012]$} & {$[0.000]$} \\
\hline \multirow[t]{2}{*}{ Polarization } & $-0.106 * * *$ & $0.247 * *$ & $-0.112 * * *$ \\
\hline & {$[0.001]$} & {$[0.043]$} & {$[0.001]$} \\
\hline \multicolumn{4}{|l|}{ Elections and stability } \\
\hline \multirow[t]{2}{*}{ Election year } & $-0.085^{*}$ & -0.210 & $-0.081 *$ \\
\hline & {$[0.061]$} & [0.533] & {$[0.076]$} \\
\hline \multirow[t]{2}{*}{ Pre-election year } & -0.063 & 0.003 & -0.064 \\
\hline & {$[0.130]$} & [0.993] & {$[0.125]$} \\
\hline \multirow[t]{2}{*}{ New elected executive } & -0.021 & -0.400 & -0.010 \\
\hline & [0.659] & {$[0.344]$} & [0.827] \\
\hline \multirow[t]{2}{*}{ New elected gov. party } & -0.041 & $-0.642 * *$ & -0.025 \\
\hline & {$[0.558]$} & [0.049] & {$[0.720]$} \\
\hline \multirow[t]{2}{*}{ Executive tenure } & 0.001 & 0.025 & -0.000 \\
\hline & [0.945] & [0.416] & [0.969] \\
\hline \multirow[t]{2}{*}{ Government party tenure } & -0.001 & 0.005 & -0.001 \\
\hline & [0.919] & {$[0.658]$} & {$[0.901]$} \\
\hline \multirow[t]{2}{*}{ Drop in veto players } & $-0.151 * *$ & $-1.427 * * *$ & $-0.133 * *$ \\
\hline & {$[0.012]$} & {$[0.006]$} & {$[0.030]$} \\
\hline \multicolumn{4}{|l|}{ Ideology } \\
\hline \multirow[t]{2}{*}{ Left-wing government } & -0.271 & 0.208 & -0.272 \\
\hline & {$[0.264]$} & {$[0.566]$} & {$[0.258]$} \\
\hline \multirow[t]{2}{*}{ Right-wing government } & -0.251 & -0.457 & -0.253 \\
\hline & [0.292] & {$[0.653]$} & {$[0.285]$} \\
\hline
\end{tabular}

Note: this table reports PPML estimation results of the marginal effects of political variables on end-year US government bond holdings conditional on the sovereign credit rating. A country is defined as being high-risk if at least one of the rating agencies Moody's, S\&P and Fitch assigned a long-term, foreign-currency rating worse than BB- (Ba3). Each specification controls for the macroeconomic and financial market indicators reported in the baseline regressions in Table 1. The results for the control variables are available upon request. Country and time fixed effects are included, but not reported. p-values (in parentheses) are based on robust standard errors clustered at the country level. *, **, and $* * *$ indicates the $10 \%, 5 \%$, and $1 \%$ level of significance, respectively 
Table 6: The effect of political factors conditional on past default

\begin{tabular}{|c|c|c|c|}
\hline & Unconditional & Past debt crisis & No debt crisis \\
\hline \multicolumn{4}{|l|}{ Political constraints } \\
\hline \multirow[t]{2}{*}{ Checks } & $-0.164 * * *$ & 0.055 & $-0.184 * * *$ \\
\hline & {$[0.002]$} & {$[0.644]$} & {$[0.000]$} \\
\hline \multirow[t]{2}{*}{ Majority } & 0.004 & 0.008 & 0.003 \\
\hline & [0.183] & [0.203] & {$[0.346]$} \\
\hline \multirow[t]{2}{*}{ Herfindahl government } & 0.001 & $-0.018 * * *$ & 0.001 \\
\hline & {$[0.831]$} & {$[0.008]$} & {$[0.711]$} \\
\hline \multirow[t]{2}{*}{ Control of all houses } & $0.345 * * *$ & 0.353 & $0.343 * * *$ \\
\hline & {$[0.000]$} & {$[0.145]$} & {$[0.000]$} \\
\hline \multirow[t]{2}{*}{ Polarization } & $-0.106^{* * *}$ & 0.192 & $-0.106 * * *$ \\
\hline & {$[0.001]$} & [0.164] & {$[0.002]$} \\
\hline \multicolumn{4}{|l|}{ Elections and stability } \\
\hline \multirow[t]{2}{*}{ Election year } & $-0.085^{*}$ & -0.225 & $-0.077 *$ \\
\hline & {$[0.061]$} & [0.245] & [0.099] \\
\hline \multirow[t]{2}{*}{ Pre-election year } & -0.063 & -0.052 & -0.064 \\
\hline & {$[0.130]$} & {$[0.762]$} & [0.129] \\
\hline \multirow[t]{2}{*}{ New elected executive } & -0.021 & -0.339 & -0.008 \\
\hline & {$[0.659]$} & {$[0.284]$} & {$[0.861]$} \\
\hline \multirow[t]{2}{*}{ New elected gov. party } & -0.041 & -0.463 & -0.027 \\
\hline & {$[0.558]$} & {$[0.177]$} & {$[0.697]$} \\
\hline \multirow[t]{2}{*}{ Executive tenure } & 0.001 & 0.012 & 0.000 \\
\hline & {$[0.945]$} & {$[0.763]$} & {$[0.967]$} \\
\hline \multirow[t]{2}{*}{ Government party tenure } & -0.001 & -0.008 & -0.001 \\
\hline & {$[0.919]$} & {$[0.814]$} & {$[0.909]$} \\
\hline \multirow[t]{2}{*}{ Drop in veto players } & $-0.151 * *$ & $-0.659 * *$ & $-0.132 * *$ \\
\hline & {$[0.012]$} & {$[0.013]$} & {$[0.037]$} \\
\hline \multicolumn{4}{|l|}{ Ideology } \\
\hline \multirow[t]{2}{*}{ Left-wing government } & -0.271 & 0.150 & -0.275 \\
\hline & {$[0.264]$} & {$[0.754]$} & {$[0.257]$} \\
\hline \multirow[t]{2}{*}{ Right-wing government } & -0.251 & -0.766 & -0.248 \\
\hline & {$[0.292]$} & {$[0.400]$} & {$[0.296]$} \\
\hline
\end{tabular}

Note: this table reports PPML estimation results of the marginal effects of political variables on end-year US government bond holdings conditional on past default. A country is defined as having a default history if it experienced a default on sovereign debt in the past 20 years as reported in Laeven and Valencia (2012). Each specification controls for the macroeconomic and financial market indicators reported in the baseline regressions in Table 1 . The results for the control variables are available upon request. Country and time fixed effects are included, but not reported. p-values (in parentheses) are based on robust standard errors clustered at the country level. *,**, and *** indicates the $10 \%$, $5 \%$, and $1 \%$ level of significance, respectively 
Table 7: The effect of political factors conditional on democratic institutions

\begin{tabular}{|c|c|c|c|}
\hline & Unconditional & $\begin{array}{c}\text { Highly } \\
\text { democratic }\end{array}$ & Less democratic \\
\hline \multicolumn{4}{|l|}{ Political constraints } \\
\hline \multirow[t]{2}{*}{ Checks } & $-0.164 * * *$ & $-0.192 * * *$ & -0.032 \\
\hline & [0.002] & {$[0.000]$} & {$[0.792]$} \\
\hline \multirow[t]{2}{*}{ Majority } & 0.004 & 0.003 & 0.006 \\
\hline & {$[0.183]$} & {$[0.398]$} & [0.206] \\
\hline \multirow[t]{2}{*}{ Herfindahl government } & 0.001 & 0.003 & -0.007 \\
\hline & {$[0.831]$} & {$[0.374]$} & [0.189] \\
\hline \multirow[t]{2}{*}{ Control of all houses } & $0.345^{* * *}$ & $0.291 * * *$ & $0.543 * * *$ \\
\hline & {$[0.000]$} & [0.003] & {$[0.000]$} \\
\hline \multirow[t]{2}{*}{ Polarization } & $-0.106 * * *$ & $-0.109 * * *$ & -0.085 \\
\hline & {$[0.001]$} & {$[0.001]$} & {$[0.551]$} \\
\hline \multicolumn{4}{|l|}{ Elections and stability } \\
\hline \multirow[t]{2}{*}{ Election year } & $-0.085^{*}$ & $-0.121 * *$ & 0.030 \\
\hline & {$[0.061]$} & {$[0.024]$} & {$[0.698]$} \\
\hline \multirow[t]{2}{*}{ Pre-election year } & -0.063 & $-0.096^{*}$ & 0.033 \\
\hline & {$[0.130]$} & {$[0.055]$} & {$[0.638]$} \\
\hline \multirow[t]{2}{*}{ New elected executive } & -0.021 & -0.040 & 0.038 \\
\hline & {$[0.659]$} & {$[0.403]$} & {$[0.681]$} \\
\hline \multirow[t]{2}{*}{ New elected gov. party } & -0.041 & -0.078 & 0.104 \\
\hline & {$[0.558]$} & {$[0.241]$} & {$[0.490]$} \\
\hline \multirow[t]{2}{*}{ Executive tenure } & 0.001 & -0.013 & $0.027 * * *$ \\
\hline & {$[0.945]$} & {$[0.346]$} & {$[0.008]$} \\
\hline \multirow[t]{2}{*}{ Government party tenure } & -0.001 & 0.002 & -0.012 \\
\hline & {$[0.919]$} & {$[0.881]$} & {$[0.539]$} \\
\hline \multirow[t]{2}{*}{ Drop in veto players } & $-0.151 * *$ & $-0.131 *$ & $-0.241 *$ \\
\hline & {$[0.012]$} & {$[0.055]$} & [0.088] \\
\hline \multicolumn{4}{|l|}{ Ideology } \\
\hline \multirow[t]{2}{*}{ Left-wing government } & -0.271 & -0.327 & -0.005 \\
\hline & [0.264] & [0.380] & [0.988] \\
\hline \multirow[t]{2}{*}{ Right-wing government } & -0.251 & -0.304 & -0.196 \\
\hline & {$[0.292]$} & {$[0.424]$} & {$[0.513]$} \\
\hline
\end{tabular}

Note: this table reports PPML estimation results of the marginal effects of political variables on end-year US government bond holdings conditional on the development of democratic institutions. Countries with a POLITY2 score equal to or higher than nine (sample median) are defined as highly democratic. Each specification controls for the macroeconomic and financial market indicators reported in the baseline regressions in Table 1 . The results for the control variables are available upon request. Country and time fixed effects are included, but not reported. p-values (in parentheses) are based on robust standard errors clustered at the country level. *,**, and *** indicates the $10 \%, 5 \%$, and $1 \%$ level of significance, respectively. 
Table 8: The effect of political factors conditional on the political regime

\begin{tabular}{|c|c|c|c|}
\hline & Unconditional & Parliamentary & Presidential \\
\hline \multicolumn{4}{|l|}{ Political constraints } \\
\hline \multirow[t]{2}{*}{ Checks } & $-0.164 * * *$ & $-0.186 * * *$ & -0.029 \\
\hline & {$[0.002]$} & {$[0.001]$} & {$[0.827]$} \\
\hline \multirow[t]{2}{*}{ Majority } & 0.004 & 0.002 & $0.007 *$ \\
\hline & {$[0.183]$} & {$[0.573]$} & {$[0.086]$} \\
\hline \multirow[t]{2}{*}{ Herfindahl government } & 0.001 & 0.003 & -0.006 \\
\hline & {$[0.831]$} & {$[0.390]$} & {$[0.407]$} \\
\hline \multirow[t]{2}{*}{ Control of all houses } & $0.345^{* * *} *$ & $0.241 * *$ & $0.658 * * *$ \\
\hline & {$[0.000]$} & {$[0.032]$} & {$[0.000]$} \\
\hline \multirow[t]{2}{*}{ Polarization } & $-0.106^{* * *}$ & $-0.111 * * *$ & -0.047 \\
\hline & {$[0.001]$} & {$[0.003]$} & {$[0.710]$} \\
\hline \multicolumn{4}{|l|}{ Elections and stability } \\
\hline \multirow[t]{2}{*}{ Election year } & $-0.085^{*}$ & $-0.110 * *$ & -0.004 \\
\hline & {$[0.061]$} & {$[0.038]$} & [0.962] \\
\hline \multirow[t]{2}{*}{ Pre-election year } & -0.063 & $-0.085^{*}$ & -0.002 \\
\hline & {$[0.130]$} & {$[0.080]$} & {$[0.976]$} \\
\hline \multirow[t]{2}{*}{ New elected executive } & -0.021 & -0.039 & 0.026 \\
\hline & [0.659] & {$[0.433]$} & {$[0.755]$} \\
\hline \multirow[t]{2}{*}{ New elected gov. party } & -0.041 & -0.083 & 0.073 \\
\hline & {$[0.558]$} & {$[0.238]$} & {$[0.560]$} \\
\hline \multirow[t]{2}{*}{ Executive tenure } & 0.001 & -0.005 & 0.016 \\
\hline & {$[0.945]$} & {$[0.682]$} & {$[0.239]$} \\
\hline \multirow[t]{2}{*}{ Government party tenure } & -0.001 & 0.006 & -0.019 \\
\hline & [0.919] & {$[0.565]$} & {$[0.292]$} \\
\hline \multirow[t]{2}{*}{ Drop in veto players } & $-0.151 * *$ & $-0.147 * *$ & -0.179 \\
\hline & {$[0.012]$} & {$[0.035]$} & {$[0.170]$} \\
\hline \multicolumn{4}{|l|}{ Ideology } \\
\hline \multirow[t]{2}{*}{ Left-wing government } & -0.271 & $0.507 * *$ & -0.448 \\
\hline & {$[0.264]$} & {$[0.048]$} & {$[0.223]$} \\
\hline \multirow[t]{2}{*}{ Right-wing government } & -0.251 & $0.522 * *$ & -0.365 \\
\hline & [0.292] & {$[0.015]$} & {$[0.131]$} \\
\hline
\end{tabular}

Note: this table reports PPML estimation results of the marginal effects of political variables on end-year US government bond holdings conditional on the type of political regime (parliamentary versus presidential). Each specification controls for the macroeconomic and financial market indicators reported in the baseline regressions in Table 1 . The results for the control variables are available upon request. Country and time fixed effects are included, but not reported. p-values (in parentheses) are based on robust standard errors clustered at the country level. *, $* *$, and $* * *$ indicates the $10 \%, 5 \%$, and $1 \%$ level of significance, respectively. 


\section{Appendix}

Appendix Table 1: Sample coverage

\begin{tabular}{lllll}
\hline $\begin{array}{l}\text { South- and East } \\
\text { Asia }\end{array}$ & Western Europe & $\begin{array}{l}\text { American } \\
\text { continent }\end{array}$ & $\begin{array}{l}\text { Eastern Europe and } \\
\text { Central Asia }\end{array}$ & $\begin{array}{l}\text { Middle East } \\
\text { and Africa }\end{array}$ \\
\hline Australia & Austria & Argentina & Bulgaria & Egypt \\
China & Belgium & Brazil & Croatia & Ghana \\
India & Denmark & Canada & Czech Republic & Israel \\
Indonesia & Finland & Chile & Greece & Lebanon \\
Japan & France & Colombia & Hungary & Morocco \\
Malaysia & Germany & Ecuador & Kazakhstan & Tunisia \\
New Zealand & Ireland & Jamaica & Latvia & South Africa \\
Philippines & Italy & Mexico & Lithuania & \\
Singapore & Netherlands & Panama & Poland & \\
Sri Lanka & Norway & Peru & Romania & \\
South Korea & Portugal & Venezuela & Russia & \\
Thailand & Spain & & Slovakia & \\
Vietnam & Sweden & & Turkey & \\
& Switzerland & & Ukraine & \\
& United Kingdom & & & \\
\hline
\end{tabular}

Appendix Table 2: Description of variables and sources

\begin{tabular}{lll}
\hline Variable & Definition & Source \\
\hline $\begin{array}{l}\text { Political } \\
\text { Variables }\end{array}$ & $\begin{array}{l}\text { Counts the number of independent veto players in a } \\
\text { political system. Independence is determined by the level } \\
\text { of electoral competitiveness in a system, party affiliations, } \\
\text { electoral rules and ideological orientation. }\end{array}$ & $\begin{array}{l}\text { Database of Political } \\
\text { Institutions, World }\end{array}$ \\
Bank, Beck et al. \\
(2001)
\end{tabular}




\begin{tabular}{|c|c|c|}
\hline Variable & Definition & Source \\
\hline $\begin{array}{l}\text { New elected } \\
\text { executive }\end{array}$ & $\begin{array}{l}\text { Dummy variable, equals } 1 \text { if there is a new elected chief } \\
\text { executive }\end{array}$ & $\begin{array}{l}\text { Database of Political } \\
\text { Institutions, World } \\
\text { Bank, Beck et al. } \\
(2001)\end{array}$ \\
\hline $\begin{array}{l}\text { New elected } \\
\text { government } \\
\text { party }\end{array}$ & $\begin{array}{l}\text { Dummy variable, equals } 1 \text { if the new elected government } \\
\text { is ruled by a different party than the previous government }\end{array}$ & $\begin{array}{l}\text { Database of Political } \\
\text { Institutions, World } \\
\text { Bank, Beck et al. } \\
\text { (2001) }\end{array}$ \\
\hline $\begin{array}{l}\text { Executive } \\
\text { tenure }\end{array}$ & $\begin{array}{l}\text { The number of years the current chief executive has been } \\
\text { in power. }\end{array}$ & $\begin{array}{l}\text { Database of Political } \\
\text { Institutions, World } \\
\text { Bank, Beck et al. } \\
(2001)\end{array}$ \\
\hline $\begin{array}{l}\text { Government } \\
\text { party } \\
\text { maturity }\end{array}$ & $\begin{array}{l}\text { The number of years the current governing party has been } \\
\text { in power }\end{array}$ & $\begin{array}{l}\text { Database of Political } \\
\text { Institutions, World } \\
\text { Bank, Beck et al. } \\
\text { (2001) }\end{array}$ \\
\hline $\begin{array}{l}\text { Drop in veto } \\
\text { players }\end{array}$ & $\begin{array}{l}\text { Indicates the percentage of veto players who drop } \\
\text { from government or opposition in any given year. }\end{array}$ & $\begin{array}{l}\text { Database of Political } \\
\text { Institutions, World } \\
\text { Bank, Beck et al. } \\
(2001)\end{array}$ \\
\hline $\begin{array}{l}\text { Left-wing } \\
\text { government }\end{array}$ & $\begin{array}{l}\text { Dummy variable taking the value of one for left-wing } \\
\text { parties, characterized by the orientation of the party of the } \\
\text { chief executive with respect to economic policy. }\end{array}$ & $\begin{array}{l}\text { Database of Political } \\
\text { Institutions, World } \\
\text { Bank, Beck et al. } \\
\text { (2001) }\end{array}$ \\
\hline $\begin{array}{l}\text { Right-wing } \\
\text { government }\end{array}$ & $\begin{array}{l}\text { Dummy variable taking the value of one for right-wing } \\
\text { parties, characterized by the orientation of the party of the } \\
\text { chief executive with respect to economic policy. }\end{array}$ & $\begin{array}{l}\text { Database of Political } \\
\text { Institutions, World } \\
\text { Bank, Beck et al. } \\
\text { (2001) }\end{array}$ \\
\hline POLITY2 & $\begin{array}{l}\text { Combined polity score derived from codings of the } \\
\text { competitiveness of political participation, the openness and } \\
\text { competitiveness of executive recruitment and constraints } \\
\text { on the chief executive. Ranges from }-10 \text { (strongly } \\
\text { autocratic) to }+10 \text { (strongly democratic) }\end{array}$ & Polity IV Database \\
\hline $\begin{array}{l}\text { Worldwide } \\
\text { Governance } \\
\text { Indicators }\end{array}$ & $\begin{array}{l}\text { Index based on the Rule of Law, Regulatory quality, } \\
\text { Government effectiveness, Voice and accountability }\end{array}$ & $\begin{array}{l}\text { Worldwide } \\
\text { Governance Indicators, } \\
\text { World Bank, } \\
\text { Kaufmann et al. (2011) }\end{array}$ \\
\hline \multicolumn{3}{|l|}{$\begin{array}{l}\text { Control } \\
\text { variables }\end{array}$} \\
\hline $\begin{array}{l}\text { Government } \\
\text { gross debt }\end{array}$ & Total general government gross debt in US Dollars & $\begin{array}{l}\text { World Economic } \\
\text { Outlook Database }\end{array}$ \\
\hline $\begin{array}{l}\text { Government } \\
\text { bond return }\end{array}$ & $\begin{array}{l}\text { Average daily bond return as a percentage. Computed } \\
\text { from several government bond indices such as the JP } \\
\text { Morgan Emerging Markets Bond Index (EMBI), the } \\
\text { Global Bond Index (GBI), the Citigroup World } \\
\text { Government Bond Index (WGBI) and the Meryl Lynch } \\
\text { Government Bond Index. }\end{array}$ & Datastream \\
\hline Bond yield & $\begin{array}{l}\text { Average yield to maturity on government bonds. } \\
\text { Computed from several government bond indices such as } \\
\text { the JP Morgan Emerging Markets Bond Index (EMBI), the } \\
\text { Global Bond Index (GBI), the Citigroup World } \\
\text { Government Bond Index (WGBI) and the Meryl Lynch } \\
\text { Government Bond Index. }\end{array}$ & Datastream \\
\hline $\begin{array}{l}\text { Bond return } \\
\text { correlation }\end{array}$ & $\begin{array}{l}\text { Correlation coefficient between daily local government } \\
\text { bond returns and US treasury bond returns. }\end{array}$ & Datastream \\
\hline Equity return & $\begin{array}{l}\text { Average daily local equity returns computed from equity } \\
\text { market indices. }\end{array}$ & Datastream \\
\hline $\begin{array}{l}\text { Exchange } \\
\text { rate return }\end{array}$ & $\begin{array}{l}\text { Average daily exchange rate return of the local currency } \\
\text { against the US Dollar. A positive return is equivalent to an } \\
\text { appreciation of the local currency. }\end{array}$ & Datastream \\
\hline
\end{tabular}




\begin{tabular}{|c|c|c|}
\hline Variable & Definition & Source \\
\hline $\begin{array}{l}\text { Sd(bond } \\
\text { return) }\end{array}$ & Standard deviation of daily bond returns & Datastream \\
\hline $\begin{array}{l}\text { Sd(equity } \\
\text { return) }\end{array}$ & Standard deviation of daily equity returns & Datastream \\
\hline $\begin{array}{l}\text { Sd(exchange } \\
\text { rate) }\end{array}$ & Standard deviation of daily returns on the exchange rate & Datastream \\
\hline $\begin{array}{l}\text { High credit } \\
\text { risk }\end{array}$ & $\begin{array}{l}\text { Dummy variable taking the value of one if at least one of } \\
\text { the three main rating agencies (Moody's, S\&P, Fitch) } \\
\text { reports a high credit risk (rating worse than BB-/Ba3) on } \\
\text { long-term foreign currency sovereign debt. }\end{array}$ & Moody’s, S\&P, Fitch \\
\hline $\begin{array}{l}\text { Bilateral } \\
\text { trade }\end{array}$ & $\begin{array}{l}\text { Ratio of exports plus imports relative to US GDP as a } \\
\text { percentage. }\end{array}$ & OECD.stat \\
\hline $\begin{array}{l}\text { Capital } \\
\text { account } \\
\text { openness }\end{array}$ & $\begin{array}{l}\text { Index measuring the extensity of capital controls based on } \\
\text { IMF reports. }\end{array}$ & Chinn and Ito (2007) \\
\hline Inflation & Yearly change of the Consumer Price Index (CPI) & $\begin{array}{l}\text { World Development } \\
\text { Indicators }\end{array}$ \\
\hline GDP growth & Annual percentage change in GDP & $\begin{array}{l}\text { World Development } \\
\text { Indicators }\end{array}$ \\
\hline $\begin{array}{l}\text { Current } \\
\text { account }\end{array}$ & Current account balance as a percentage of GDP & $\begin{array}{l}\text { World Economic } \\
\text { Outlook Database }\end{array}$ \\
\hline $\begin{array}{l}\text { Fiscal } \\
\text { balance }\end{array}$ & $\begin{array}{l}\text { General government total revenues minus total expenses, } \\
\text { as a percentage of GDP }\end{array}$ & $\begin{array}{l}\text { World Economic } \\
\text { Outlook Database }\end{array}$ \\
\hline
\end{tabular}

Appendix Table 3: Summary statistics

\begin{tabular}{lcccc}
\hline Variable & Mean & Min & Max & $\begin{array}{c}\text { Std. Dev. } \\
\text { (Within) }\end{array}$ \\
\hline US bond holdings & 7,974 & 0 & 116,848 & 5,524 \\
Political variables & 7.330 & -7 & 10 & 0.949 \\
POLITY2 & 3.649 & 1 & 17 & 0.961 \\
Checks & 59.186 & 9.278 & 100 & 8.331 \\
Majority & 73.565 & 18.417 & 100 & 10.141 \\
Herfindahl government & 0.325 & 0 & 1 & 0.212 \\
Control of all houses & 0.238 & 0 & 1 & 0.418 \\
Election year & 0.244 & 0 & 1 & 0.422 \\
Pre-election year & 0.135 & 0 & 1 & 0.331 \\
New elected executive & 0.112 & 0 & 1 & 0.302 \\
New elected gov. party & 4.543 & 1 & 30 & 2.924 \\
Executive tenure & 9.348 & 1 & 65 & 3.494 \\
Government party tenure & 0.139 & 0 & 1 & 0.268 \\
Drop in veto players & 0.428 & 0 & 1 & 0.324 \\
Left-wing government & 0.418 & 0 & 1 & 0.355 \\
Right-wing government & & & & 1 \\
\end{tabular}




\begin{tabular}{|c|c|c|c|c|}
\hline Variable & Mean & Min & Max & $\begin{array}{l}\text { Std. Dev. } \\
\text { (Within) }\end{array}$ \\
\hline Polarization & 0.764 & 0 & 2 & 0.459 \\
\hline \multicolumn{5}{|l|}{ Control variables } \\
\hline Government gross debt & 543,470 & 1,891 & $14,100,000$ & 372,595 \\
\hline Government bond return & 0.029 & -0.500 & 0.325 & 0.062 \\
\hline Exchange rate return & 0.002 & -0.277 & 0.170 & 0.040 \\
\hline Bond yield & 5.386 & 0.350 & 56.884 & 3.075 \\
\hline Equity return & 0.041 & -0.675 & 0.677 & 0.147 \\
\hline Bond return correlation & 0.153 & -0.443 & 0.969 & 0.220 \\
\hline Sd(equity return) & 1.535 & 0.166 & 20.626 & 0.938 \\
\hline Sd(bond return) & 0.637 & 0.039 & 3.151 & 0.299 \\
\hline Sd(exchange rate) & 0.561 & 0 & 3.258 & 0.250 \\
\hline High credit risk & 0.142 & 0 & 1 & 0.157 \\
\hline Bilateral trade & 0.345 & 0.003 & 4.076 & 0.105 \\
\hline Capital account openness & 73.323 & 0 & 100 & 8.901 \\
\hline Inflation & 4.537 & -4.480 & 31.091 & 2.615 \\
\hline GDP growth & 3.383 & -14.814 & 18.287 & 3.061 \\
\hline Current account & -0.096 & -24.323 & 25.974 & 3.242 \\
\hline Fiscal balance & -2.147 & -32.418 & 18.458 & 2.708 \\
\hline
\end{tabular}




\section{References}

Acharya, V. V., and Steffen, S. (2015). The "greatest" carry trade ever? Understanding eurozone bank risks. Journal of Financial Economics, 115(2), 215-236.

Afonso, A., Furceri, D., and Gomes, P. (2012). Sovereign credit ratings and financial markets linkages: application to European data. Journal of International Money and Finance, 31(3), 606-638.

Alesina, A., and Drazen, A. (1991). Why are Stabilizations Delayed? American Economic Review, 82, 1-170.

Angeloni, C., and Wolff, G. B. (2012). Are banks affected by their holdings of government debt? Bruegel Working Paper 2012/07.

Battistini, N., Pagano, M., and Simonelli, S. (2013). Systemic risk and home bias in the euro area. European Commission Directorate General Economic and Monetary Affairs Economic Papers No. 494.

Beck, T., Clarke, G., Groff, A., Keefer, P., and Walsh, P. (2001). New tools in comparative political economy: The Database of Political Institutions. The World Bank Economic Review, 15(1), 165-176

Bertaut, C. C., and Judson, R. (2014). Estimating US cross-border securities positions: New data and new methods. FRB International Finance Discussion Paper No. 1113.

Block, S. A., and Vaaler, P. M. (2004). The price of democracy: sovereign risk ratings, bond spreads and political business cycles in developing countries. Journal of International Money and Finance, 23(6), 917-946.

Boubakri, N., Cosset, J. C., and Smaoui, H. (2011). Political Institutions and Sovereign Credit Spreads. Politics and Economic Development, 97. 
Breen, M., and McMenamin, I. (2013). Political institutions, credible commitment, and sovereign debt in advanced economies. International Studies Quarterly, 57(4), 842-854.

Buch, C. M., Koetter, M., and Ohls, J. (2013). Banks and sovereign risk: a granular view. Deutsche Bundesbank Discussion Papers No. 29/2013.

Burger, J. D., and Warnock, F. E. (2003). Diversification, original sin, and international bond portfolios. International Finance Discussion Papers No. 755

Burger, J. D., Sengupta, R., Warnock, F. E., and Warnock, V. C. (2014). US investment in global bonds: As the Fed pushes, some EMEs pull. National Bureau of Economic Research No. w20571.

Chinn, M. D., and Ito, H. (2007). A New Measure of Financial Openness. Department of Economics, University of Wisconsin. mimeo.

Cuadra, G., and Sapriza, H. (2008). Sovereign default, interest rates and political uncertainty in emerging markets. Journal of International Economics, 76(1), 78-88.

De Bruyckere, V., Gerhardt, M., Schepens, G., and Vander Vennet, R. (2013). Bank/sovereign risk spillovers in the European debt crisis. Journal of Banking and Finance, 37(12), 4793-4809.

Eichler, S. (2014). The political determinants of sovereign bond yield spreads. Journal of International Money and Finance, 46, 82-103.

Ferreira, M. A., and Miguel, A. F. (2011). The determinants of domestic and foreign bond bias. Journal of Multinational Financial Management, 21(5), 279-300.

Fidora, M., Fratzscher, M., and Thimann, C. (2007). Home bias in global bond and equity markets: the role of real exchange rate volatility. Journal of International Money and Finance, 26(4), 631-655. 
Gennaioli, N., Martin, A., and Rossi, S. (2014). Banks, government bonds, and default: what do the data say? European Corporate Governance Institute (ECGI)-Finance Working Paper No. 425.

Hibbs, D. A. (1977). Political parties and macroeconomic policy. American Political Science Review, 71(04), 1467-1487.

Huang, T., Wu, F., Yu, J., and Zhang, B. (2015). International political risk and government bond pricing. Journal of Banking and Finance, 55, 393-405.

Kaufmann, D., Kraay, A., and Mastruzzi, M. (2011). The worldwide governance indicators: methodology and analytical issues. Hague Journal on the Rule of Law, 3(02), 220-246.

Keefer, P., and Stasavage, D. (2003). The limits of delegation: Veto players, central bank independence, and the credibility of monetary policy. American Political Science Review, 97(03), 407-423.

Kohlscheen, E. (2010). Sovereign risk: Constitutions rule. Oxford Economic Papers, 62(1), 6285.

Laeven, L., and Valencia, F. (2012). Systemic banking crises database: An update. IMF Working Paper No. 12/163.

Lane, P. R. (2005). Global bond portfolios and EMU. ECB Working Paper Series No. 553

Manasse, P., and Roubini, N. (2009). "Rules of thumb" for sovereign debt crises. Journal of International Economics, 78(2), 192-205.

Reinhart, C. M., Rogoff, K. S., and Savastano, M. A. (2003). Debt intolerance. National Bureau of Economic Research Working Paper No. 9908.

Saiegh, S. M. (2009). Coalition governments and sovereign debt crises. Economics and Politics, 21(2), 232-254. 
Silva, J. S., and Tenreyro, S. (2006). The log of gravity. The Review of Economics and Statistics, 88(4), 641-658.

Tsebelis, G. (2002). Veto players: How political institutions work. Princeton University Press.

Vaaler, P. M., Schrage, B. N., and Block, S. A. (2006). Elections, opportunism, partisanship and sovereign ratings in developing countries. Review of Development Economics, 10(1), 154-170.

Vanpée, R., and De Moor, L. (2013). Bond and equity home bias and foreign bias: An international study. KU Leuven, AFI-1269.

Van Rijckeghem, C., and Weder, B. (2009). Political institutions and debt crises. Public Choice, 138(3-4), 387-408. 